\title{
Integrated Model of Bioenergy and Agriculture System
}

\section{Sigurjonsson, Hafthor ÆEgir; Elmegaard, Brian; Clausen, Lasse Røngaard}

\section{Published in:}

Proceedings - The 56th Conference on Simulation and Modelling (SIMS 56)

Link to article, DOI:

10.3384/ecp15119211

Publication date:

2015

Document Version

Publisher's PDF, also known as Version of record

Link back to DTU Orbit

Citation (APA):

Sigurjonsson, H. Æ., Elmegaard, B., \& Clausen, L. R. (2015). Integrated Model of Bioenergy and Agriculture System. In Proceedings - The 56th Conference on Simulation and Modelling (SIMS 56) (pp. 211-228). Linköping University Electronic Press. Linköping Electronic Conference Proceedings https://doi.org/10.3384/ecp15119211

\section{General rights}

Copyright and moral rights for the publications made accessible in the public portal are retained by the authors and/or other copyright owners and it is a condition of accessing publications that users recognise and abide by the legal requirements associated with these rights.

- Users may download and print one copy of any publication from the public portal for the purpose of private study or research.

- You may not further distribute the material or use it for any profit-making activity or commercial gain

- You may freely distribute the URL identifying the publication in the public portal 


\title{
Integrated model of bioenergy and agriculture system
}

\author{
Hafthor Ægir Sigurjonsson ${ }^{1} \quad$ Brian Elmegaard $^{1} \quad$ Lasse Røngaard Clausen $^{1}$ \\ ${ }^{1}$ DTU Mechanical Engineering, Technical University of Denmark (DTU), Denmark, \\ $\{$ hafsig, be, Irc\}@mek.dtu.k
}

\begin{abstract}
Due to increased burden on the environment caused by human activities, focus on industrial ecology designs are gaining more attention. In that perspective an environmentally effective integration of bionergy and agriculture systems has significant potential. This work introduces a modeling approach that builds on Life Cycle Inventory and carries out Life Cycle Impact Assessment for a consequential Life Cycle Assessment on integrated bioenergy and agriculture systems. The model framework is built in Python which connects various freely available software that handle different aspects of the overall model. CTOOL and Yasso07 are used in the carbon balance of agriculture, Dynamic Network Analysis is used for the energy simulation and Brightway2 is used to build a Life Cycle Inventory compatible database and processes it for various impacts assessment methods. The model is successfully demonstrated using a manure utilization case study where the manure is used to produce biogas and then heat and power, whereas its digestate is used as an organic fertilizer to a wheat field. The case study is compared with direct manure to wheat field application.
\end{abstract}

Keywords: Life cycle assessment, energy efficiency, sustainability

\section{Introduction}

Environmental conscious design of industrial systems has gained more interest in recent years and the development of industrial ecosystems and eco-industrial parks are now relevant topics for policy-makers. This is in large part due to increasing public awareness of the environmental burden from human activity on the environment. Denmark's future energy plan for 2050 is to be completely independent of fossil fuels for all energy consumption in the country (Danish Ministry of Climate. Energy and Buildings). This includes all electricity and heat consumption, along with transportation fuels. For this to be possible and make sense, the utilization of energy resources needs to be environmentally effective and the available options going forward need to be thoroughly investigated. Along with this focus on more environmentally friendly energy system in Denmark, the environmental burden of its agricultural in- dustry also needs to addressed, which today releases about $15 \%$ of the total national greenhouse gas emissions (Government (2013a)). A climate change mitigation potentials inter-ministerial working group report identified a few connection with the energy industry to mitigate those emissions (Government (2013b)).

Finding the best possible integration between these two industries in terms of net environmental impact is the motivation of this work. Systems are analyzed using the Life Cycle Assessment framework (LCA) (Rebitzer et al. (2004)) using the Brightway2 software (Mutel (2015)). Building the Life Cycle Inventory (LCI) (Suh and Huppes (2005)) requires detailed models of the inputs and outputs of the agricultural and energy systems, along with possible interactions between them. Integration between bioenergy and agriculture can be done in various ways. In this work the focus has been on producing electricity and district heat by using residual resources in the agricultural system and thus not affect its capacity to produce food and related products. Additionally, the organic residues from the biomass conversion in the energy system are returned back to the agricultural system to ensure that most of the essential elements, e.g. macro-nutrient, for agricultural activities are recycled. The agricultural system base model is a field which mainly produces wheat grain, located in Zealand Denmark. In its reference state, it is fertilized with mineral fertilizers and has expected yield according to the national agricultural guidelines (NaturErhvervstyrelsen (2013)). The LCI model is built on top of an extensive model gathered from the Ecoinvent 3 database (Weidema et al. (2013)) and follows their basic modeling principles, in addition to a comprehensive atmospheric carbon balance modeling procedure adopted from (Cherubini et al. (2011) and Petersen et al. (2013)) and using results generated by the soil carbon balance simulation software C-TOOL (Petersen et al. (2002) and Petersen et al. (2005)). The energy system utilizes biomass resources and can be either based on biochemical or thermochemical conversion (or both) before heat and power generation in a gas engine or a steam cycle and will always deliver its residues to the agricultural system as organic fertilizer. Modeling of the energy system is done in the Dynamic Network Analysis (DNA) (Elmegaard and Houbak (2005)). Like the agricultural system the energy 
system LCI model is built on top of a model gathered from Ecoinvent 3 but using results from DNA. The Life Cycle Impact Assessment (Pennington et al. (2004)) results are given in four levels, from a normalized and weighted endpoint result combining seventeen different environmental indicators into one numerical result to disaggregating the most important indicators to specific inputs and outputs of the system analyzed using midpoint level LCIA. This is to allow for evaluation of the total environmental impact and what inputs and outputs are mostly effecting that outcome.

This articles describes the methodology of the integrated agriculture and bioenergy environmental impact assessment model. How the LCIs are built from mass, energy and substance balances of the sub-systems, and how the four levels LCIA analysis gives overall environmental impact and the major contributors to that impact as a result. The model is demonstrated by analyzing manure based biogas production and utilization. Additionally, a direct manure to field application is analyzed as a reference case.

\section{Method}

\subsection{Case description}

The modeling and analysis methods introduced in this paper are demonstrated by a case study on biogas production and utilization from pig manure, and a reference case with direct pig manure to field application. The objective of the analysis is to report the environmental impact change to one hectare agricultural field and to identify the main impacts and contributors to the final result. A simple flow chart of the system can be seen in Figure 1.

The system for each case is divided into three subsystems, i.e. agricultural, storage and transportation, and energy. The energy sub-system consist of the biochemical conversion of biomass to biogas, and heat and power generation. Before the pig manure is converted to biogas and digestate, it is stored and then de-watered in a decanter. The liquid manure is stored in an outdoor storage before it is applied to the agricultural sub-system. However, the solid manure is converted in an anaerobic digester to biogas and digestate. The digestate follows the same process as the liquid manure, but the biogas is combusted in a gas engine producing electricity and district heat.

The agricultural sub-system is a cereal grain production using conventional practices. For the analysis the manure is modeled as a recycled content (Frischknecht (2010)), i.e. only the impacts it induces follow the flow and other parts of the pork production are excluded. Moreover, as raw manure, liquid manure or digestate are applied to the field its effective macro-nutrient content replaces mineral fertilizer and modifies the field emissions.

\subsection{Model formulation}

\subsubsection{Agricultural sub-system model}

The objective of this model is to produce a Life Cycle Inventory (LCI) of the system described by the user. A database is used to form the base of a LCI, which is then manipulated and modified based on the actual condition and substance balances of the system. To describe that process the agricultural sub-system model is divided into three modeling sections representing, nutrients-, carbonand heavy metals balance which will deliver new unit processes and elementary flows for the LCI.

The nutrient balance model is based on the macronutrients required to grow crops, i.e. nitrogen $(\mathrm{N})$, phosphorus $(\mathrm{P})$ and potassium $(\mathrm{K})$. The flow of these nutrients through the system are governed by conservation of mass and each substance is modeled individually. Only N is modeled to change in the control volume by immobilization and mineralization in the agricultural soil, for both $\mathrm{P}$ and $\mathrm{K}$ the outputs are equal to the inputs.

The reference mineral fertilization is based on national guidelines for fertilization (NaturErhvervstyrelsen (2013)) and the change in nutrient balance is regulated by the mineral fertilizer input. Uptake by harvest, grain and straw (if harvested), are a part of the nutrient output of a field. The uptake by grain is based on the yield and its chemical composition. Yields are assumed based on the soil type using national guidelines (NaturErhvervstyrelsen (2013)) and chemical composition is extracted from a biomass database adopted from (Vassilev et al. (2010)). Same principles apply to straw, along with extraction efficiency, i.e. how much of the total straw are harvested. For P model, leaching, surface run-off and erosion are included and estimated based on (Nemecek and Schnetzer (2012)). Figures 2 and 3 display the phosphorus inputs and output of the agricultural sub-system.

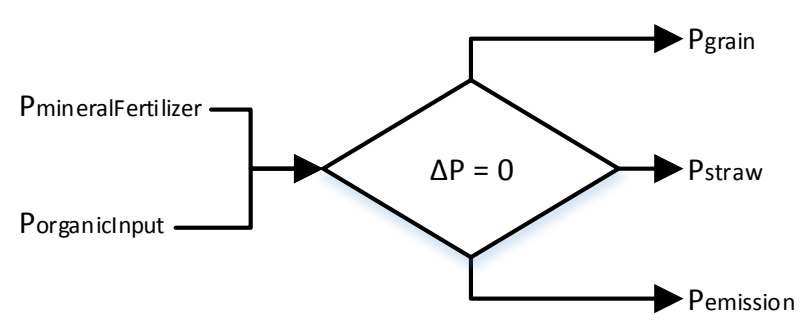

Figure 2. Phosphorus balance in the agricultural sub-system.

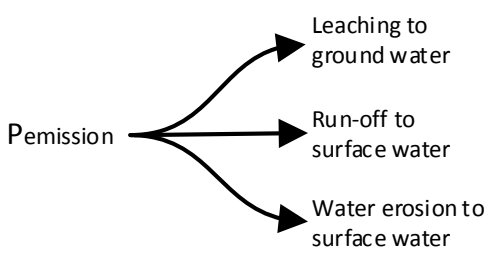

Figure 3. Phosphorus emissions in the agricultural sub-system. 


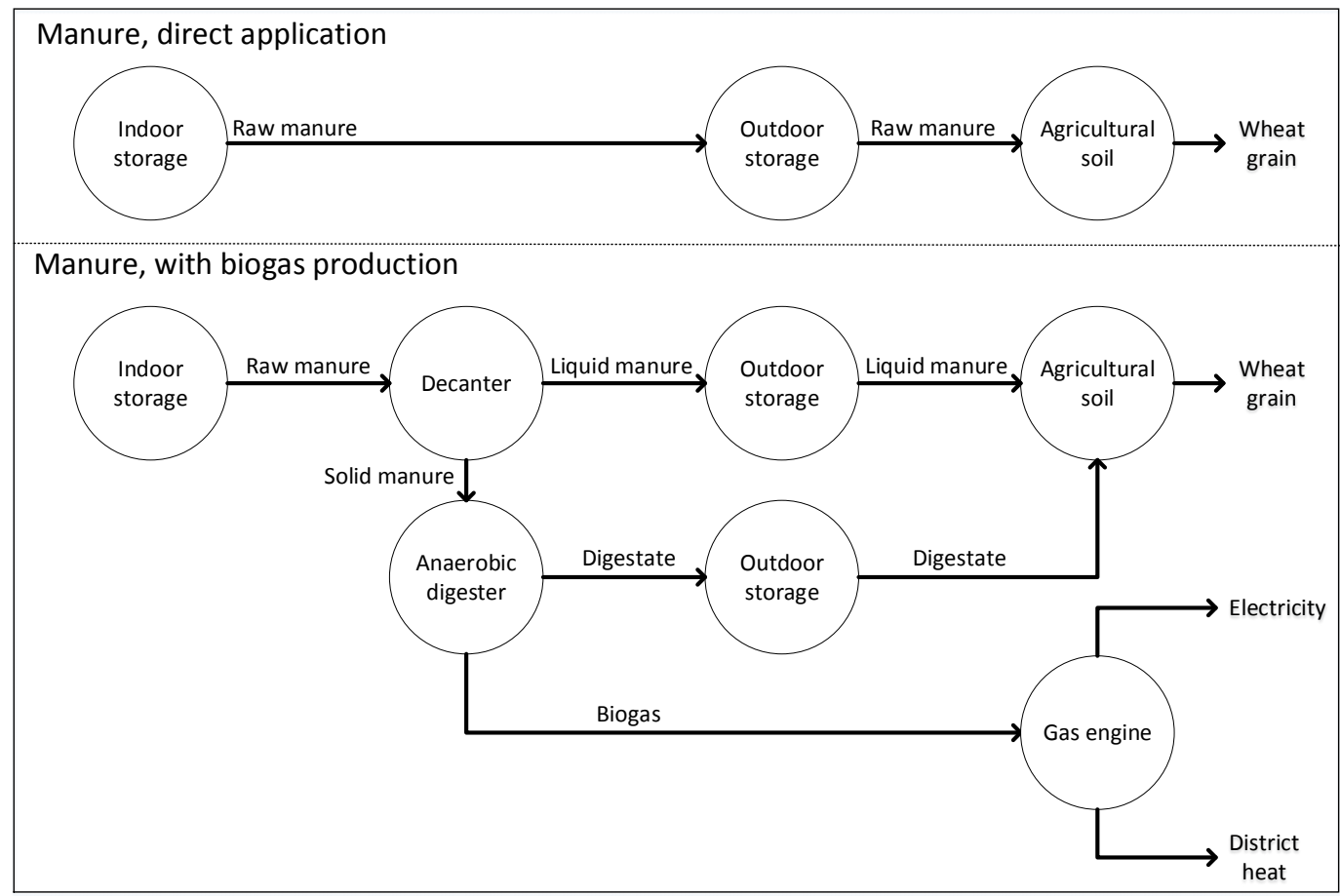

Figure 1. Flow diagram for the case study and the reference.

$\mathrm{K}$ model also includes leaching as an emission, but the calculations are based on a method adopted from (de Willigen (2000)) recommended by Food and Agriculture Organization (FAO) in Assessment of nutrient balances: Approaches and methodologies (Roy et al. (2003)). Figures 4 and 5 display the potassium inputs and output of the agricultural sub-system.

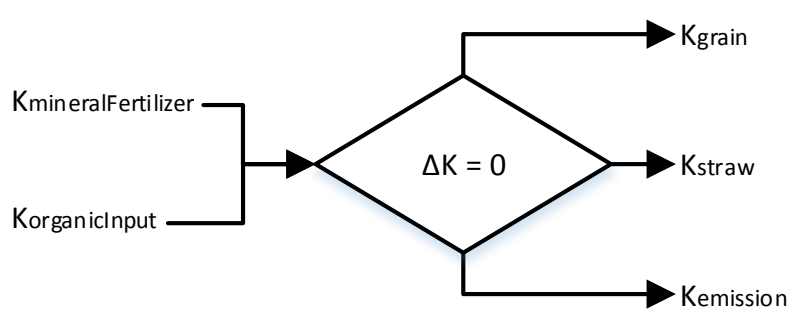

Figure 4. Potassium balance in the agricultural sub-system.

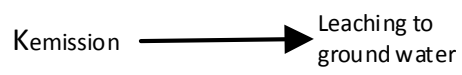

Figure 5. Potassium emissions in the agricultural sub-system.

Nitrogen outputs include leaching $\left(\mathrm{NO}_{3}^{-}\right)$, along with nitrous oxide $\left(\mathrm{N}_{2} \mathrm{O}\right)$, nitrogen gas $\left(\mathrm{N}_{2}\right)$ and ammonia $\left(\mathrm{NH}_{3}\right)$ emissions. These nitrogen outputs are calculated in different ways depending on the input resource. Figures 6 and 7 display the nitrogen inputs and output of the agricultural sub-system.

For pig manure sourced inputs (raw slurry, liquid fraction, solid fraction, digestate, liquid digestate and solid digestate) the nitrogen outputs were calculated using the

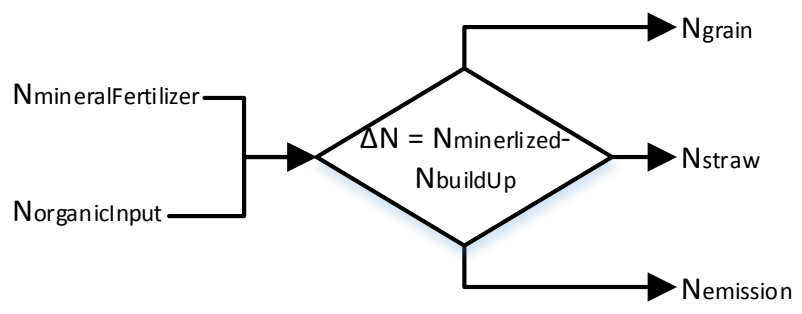

Figure 6. Nitrogen balance in the agricultural sub-system.

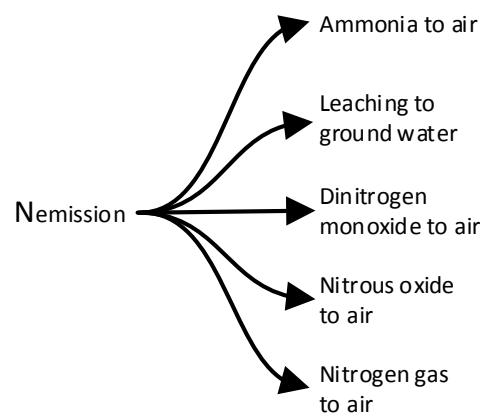

Figure 7. Nitrogen emissions in the agricultural sub-system.

same methods as in (Hamelin et al. (2011)). The methods of assessing direct field emissions for LCIs of agricultural production sub-system (Nemecek and Schnetzer (2012)) are used for mineral and cereal straw sourced inputs.

The carbon (C) balance model is based on the flow through the whole system and follows the law of mass conservation. Similarly to the nutrient balance model the C output of the agricultural sub-system is based on the uptake (photosynthesis) by harvest and associated emis- 
sion. However, the input is equal to the total carbon captured by photosynthesis of the whole growth on the field (harvest and residues) in addition to any organic or inorganic $\mathrm{C}$ input through fertilization. The uptake is based on the chemical composition, yield and extraction efficiency in the same manner as described above. Figures 8 and 9 display the carbon inputs and output of the agricultural sub-system. Additionally, to describe the photosynthe-

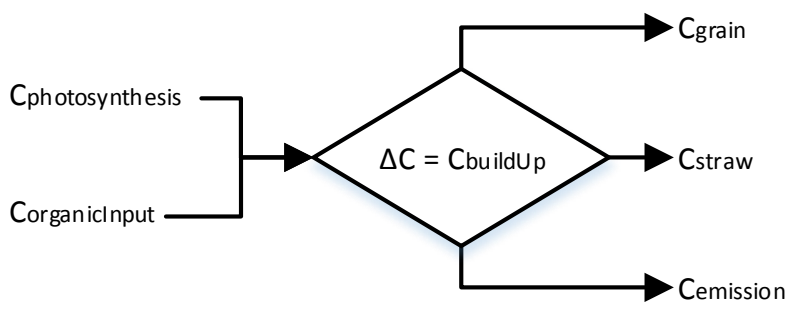

Figure 8. Carbon balance in the agricultural sub-system.

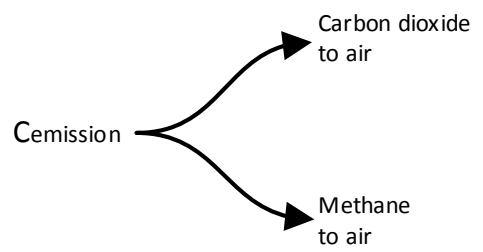

Figure 9. Carbon emissions in the agricultural sub-system.

sis the growth period displayed in Figure 10 is simulated based on the Schnute model (Schnute (1981)), a versatile growth model based on statistically stable parameters. C

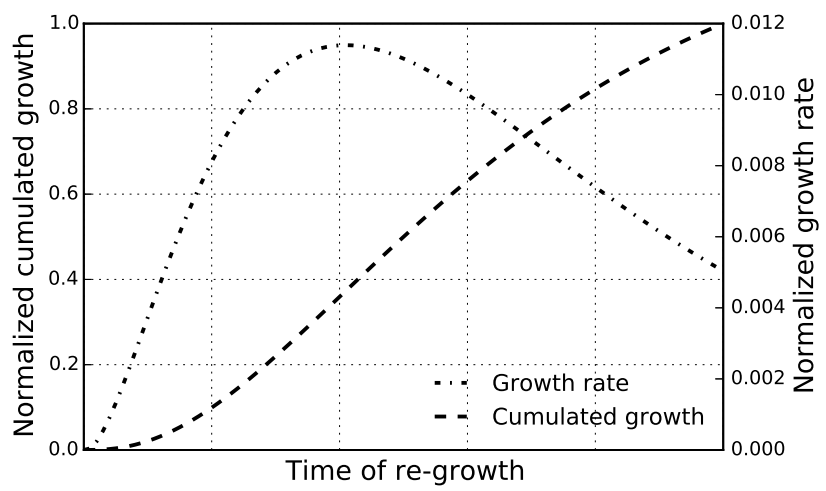

Figure 10. Carbon captured by photosynthesis in the agricultural and forestry sub-system.

emissions from the agricultural sub-system is based on the respiration of decaying residues and organic fertilizer. The magnitude of these residues is based on the straw extraction efficiency and any other organic input to the soil. C decay from the residues and other organic carbon inputs are simulated by C-TOOL (Petersen et al. (2002, 2005)), a software for whole-profile carbon storage simulation in temperate agricultural soils. This also needs to be considered for other biomass potentially utilized in the overall system. C balance for a wood chips feedstock is thus modeled in a forest sub-system. That model follows the same principles as the agricultural sub-system but uses data extracted from Yasso07 (Liski et al. (2005)), a carbon and decomposition software for forest soils, to simulate the decay of forest residues. It can be seen in Figure 11, that the

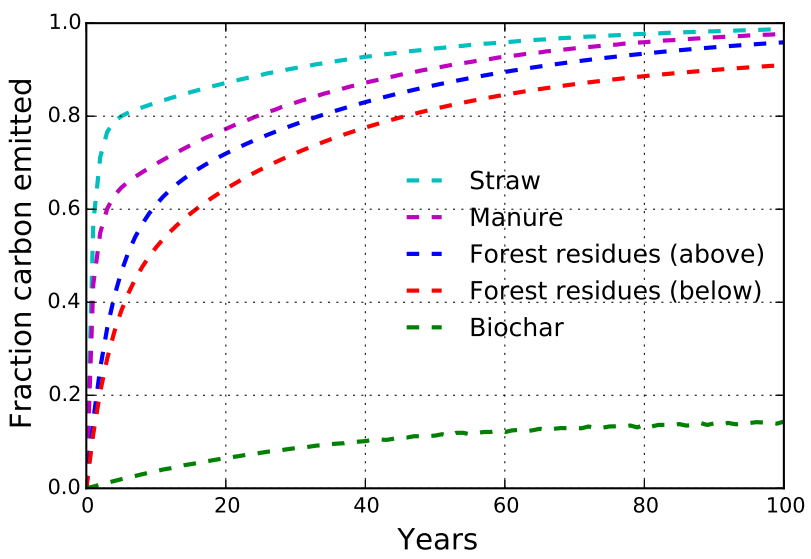

Figure 11. Carbon emissions from decomposition in the agricultural and forestry sub-system.

carbon emission from decaying biomass is gradual over time. The impact factor related to greenhouse gas emissions is in reference of pulse emission of carbon dioxide, i.e. all carbon is emitted in the first year, but the influence on climate change is then based on the integrated radiative forcing of carbon dioxide in the atmosphere. Thus the load of carbon dioxide in the atmosphere needs to adequately accounted for in the case of biomass decay carbon dioxide emissions. When emitted it starts to be absorbed by earth's many sink, e.g. ocean and terrestrial forests, this is simulated by the impulse response function (Joos et al. $(1996,2001))$ which needs to be combined with the biomass decay emissions to get their atmospheric load over a time horizon. Figure 12, displays the atmospheric load of carbon emission from different sources in reference to pulse emitted $\mathrm{CO}_{2}$. The global warming potential

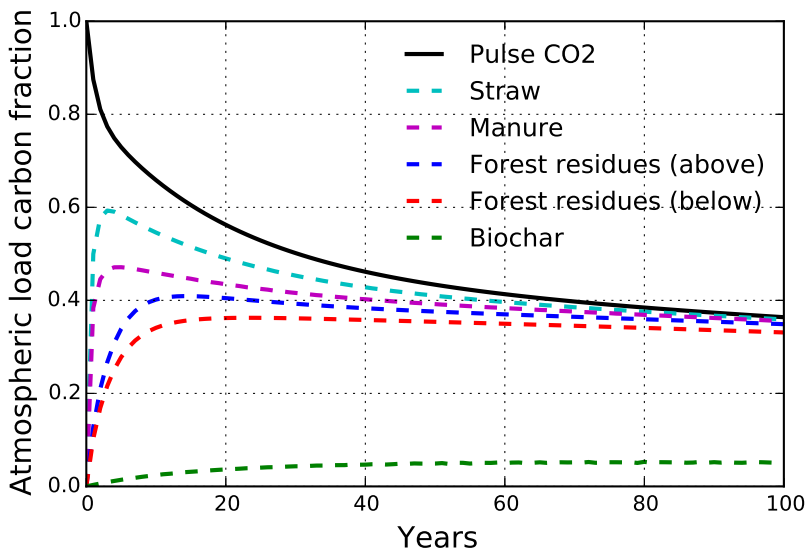

Figure 12. Atmospheric load due to carbon dioxide emissions. 
for the biomass decay carbon dioxide emission can then be calculated by referencing their atmospheric load to that of the pulse carbon dioxide. The global warming potential of the different biomass decay emissions is displayed graphically overt time in Figure 13.

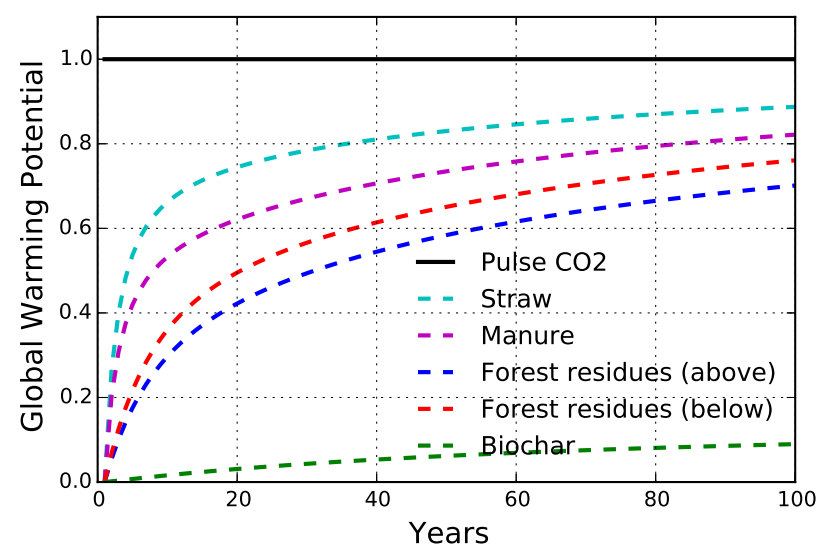

Figure 13. Evolution of the global warming potential over time.

It can be seen in Figure 13 the curve representing manure ends at a value about 0.81 . This indicates that the global warming potential of $1 \mathrm{~kg}$ manure carbon dioxide decay is about $0.81 \mathrm{~kg}$ carbon dioxide equivalent. However, there are two elements to the total global warming potential of a biomass and the other is the sub-sequent regrowth of carbon in the biomass type. This is described in Figure 10 above, and for carbon in manure which mainly comes from annual rotation agricultural crops the value is -1 as its carbon is captured within a year.

The Heavy metals balance model is like the other balance models based on the flow through the whole system and follows the law of mass conservation. The heavy metals modeled are: Cadmium $(\mathrm{Cd})$, copper $(\mathrm{Cu})$, zinc $(\mathrm{Zn})$, lead $(\mathrm{Pb})$, nickel $(\mathrm{Ni})$, chromium $(\mathrm{Cr})$ and mercury $(\mathrm{Hg})$. Inputs to the agricultural field are based on the heavy metals content of fertilizers, pesticides, seeds and disposition. The heavy metals can either accumulate or diminish from the soil based on the balance and are accounted for as emission to the soil (can be positive or negative). For the reference system the emissions are modeled according to ecoinvent modules which use SALCA-heavy metal (Nemecek and Schnetzer (2012)) as its reference. The emission is divided between soil emissions, leaching to ground water and erosion to surface water. Figures 14 and 15 display the heavy metals inputs and output of the agricultural sub-system. The leaching and erosion are modeled in SALCA-heavy metal based on constants, so when inputs change in the reference system the accumulation or demission in soil is only affected, thus causing increase or decrease in soil emissions.

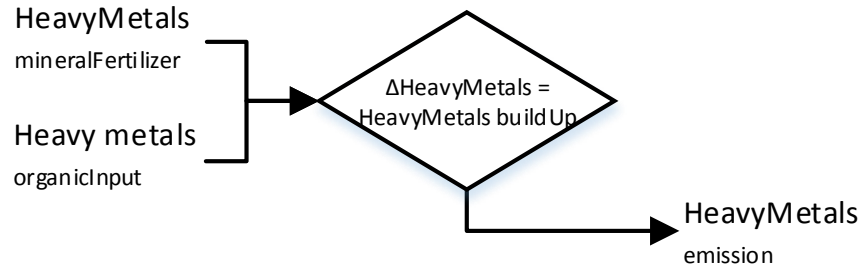

Figure 14. Heavy metals balance in the agricultural sub-system.

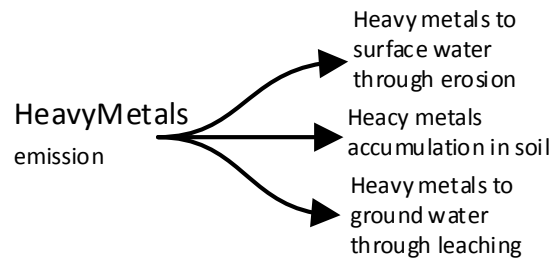

Figure 15. Heavy metals emissions in the agricultural subsystem.

\subsubsection{Energy sub-system model}

The energy sub-system is modeled with the Dynamic Network Analysis (DNA) energy system simulation tool (Elmegaard and Houbak (2005)). By using DNA it is possible to use the library of energy components already modeled there. Specific models of the energy sub-system for use in this project are modeled in DNA. In all of those pre-made models, the inputs requirements are the ultimate chemical composition, energy content and specific heat of the resource utilized. Optionally, the operation parameters which are to be varied can be defined. The ultimate chemical composition of the resource used is found in the same way as in Section 2.2.1. Additionally, the Higher Heating Value (HHV) and specific heat (cp) are estimated on a dry basis with the following equations from (Friedl et al. (2005)) and (Dupont et al. (2014)) for each resource, respectively.

$$
\begin{aligned}
H H V_{d r y} & =341.7 \cdot C+1322.1 \cdot H+119.8 \cdot(O+N) \\
& -123.2 \cdot S / 10000-15.3 \cdot A
\end{aligned}
$$

Where $\mathrm{C}, \mathrm{H}, \mathrm{O}, \mathrm{N}, \mathrm{S}, \mathrm{A}$ are the carbon, hydrogen, oxygen, nitrogen, sulfur and ash content of the resource given by its ultimate chemical composition.

$$
C P=(5.340 \cdot T(K)-299) / 1000
$$

DNA already handles all mass and energy balances over the whole energy sub-system it simulates and delivers the properties of each state of the energy sub-system and all necessary information about its products, e.g. electricity, district heat, digestate, biochar and ash, and fuel.

DNA provides information about the emissions from the power plant. For a thermochemical conversion system the power plant consists of a gasifier and either a steam cycle or a gas engine, and for a biochemical conversion system the power plant consist of an anaerobic digester 
and either a steam cycle or a gas engine. By doing all this, DNA handles the nutrient and carbon balance through the power plants. It is worth noting that the nutrient balance differs in one significant way for power plants using biochemical- or thermochemical conversions. This can be observed in Figures 16a and 16b. It can be seen the fig-

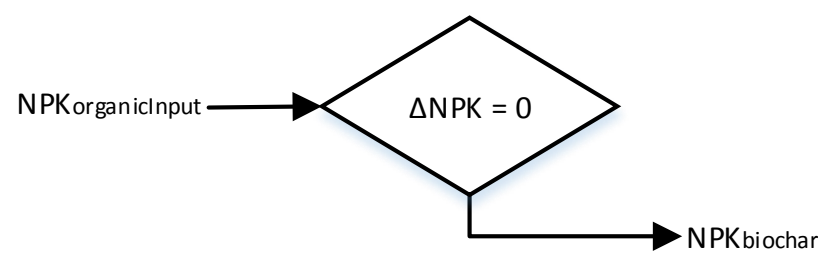

(a) Biochemical conversion

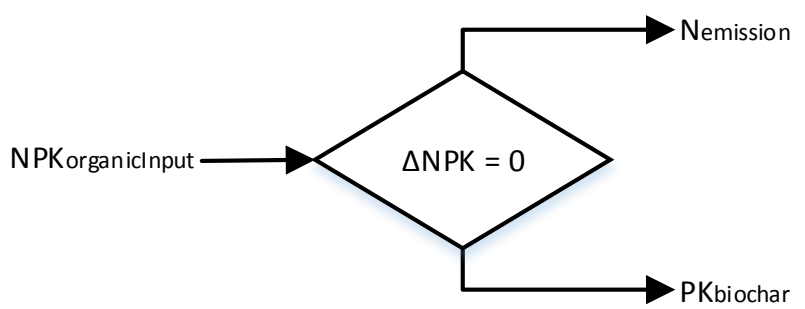

(b) Thermochemical conversion.

Figure 16. Nutrient balance for inputs to the power plants.

ures that the nitrogen input is lost as emissions when the resource is thermochemically converted, whereas it is retained in the digestate, making it available to the agricultural sub-system again, when biochemically converted.

As mentioned in above the carbon balance for the power plants is performed in DNA. The inputs and outputs from DNA are the carbon input of the organic material to be converted and then either digestate or biochar for biochemical or thermochemical conversion respectively, and emissions which can be both carbon dioxide and methane or just carbon dioxide corresponding to Figure 9 in Section 2.2.1.

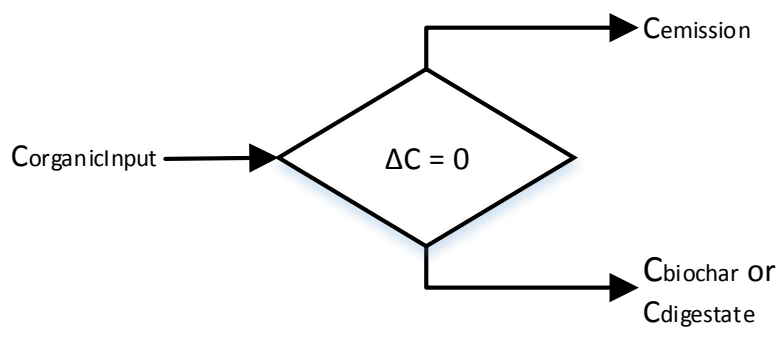

Figure 17. Carbon balance for inputs to the power plants.

\subsubsection{Storage and transportation sub-system model}

The $\mathrm{P}$ and $\mathrm{K}$ nutrient balance of the storage and transportation sub-system are modeled with an organic input and an organic output, which are equal for both P and K. However for the decanter the distribution between liquid and solid fraction differs according to (Hamelin et al. (2011)), which also gives the distribution for N. Most often the balance for $\mathrm{N}$ is equivalent to $\mathrm{P}$ and $\mathrm{K}$, but special attention is drawn to storage of manure type resources. In those cases $\mathrm{N}$ emissions need to be accounted for, which are the same as introduced in Sections 2.2.1 and 2.2.2 except nitrate leaching is added. Figures 18 and 19 display the nitrogen inputs and output of the storage and transportation sub-system. It can be seen in the figures that there

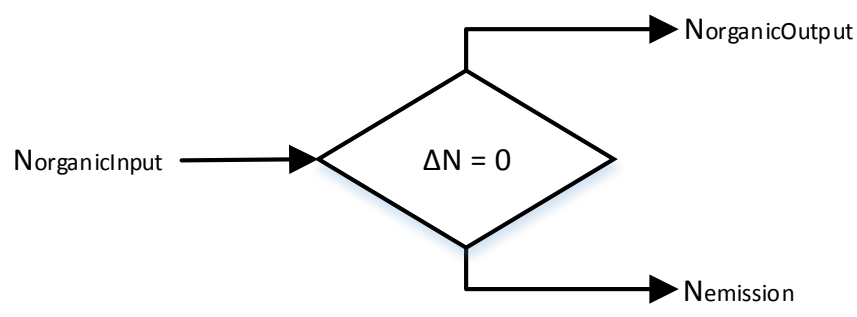

Figure 18. Nitrogen balance in the storage sub-system.

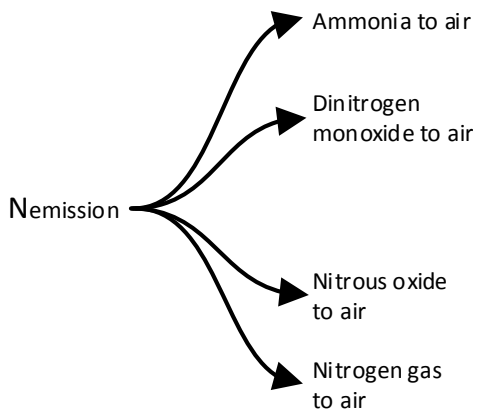

Figure 19. Nitrogen emissions in the storage sub-system.

are a-lot of similarities to Figures 6 and 7 and the amounts are calculated according to (Hamelin et al. (2011)) like for pig manure sourced emissions from agricultural field, but these emission are specific to indoor and outdoor storage.

The carbon balance is equivalent to the nitrogen balance, but with emissions corresponding to Figure 9 and the magnitude of the emissions are calculated according to (Hamelin et al. (2011)).

\subsection{Performance analysis model}

LCIA results are given in four levels, where the total endpoint results are disaggregated to each impact category and sub-system. Before the results are disaggregated to the main impact categories for each input and output of the LCI at midpoint level. Figure 20 displays the elements of the four level LCIA method.

First the total endpoint results are given. Those results give the total environmental impact asserted by the system analysed. These endpoint results are given in relation to its subcategories, i.e. ecosystem quality, human health and resources, which are then given for each sub-system. Those results are then further disaggregated into their impact subcategories; for ecosystem quality, i.e. agricul- 


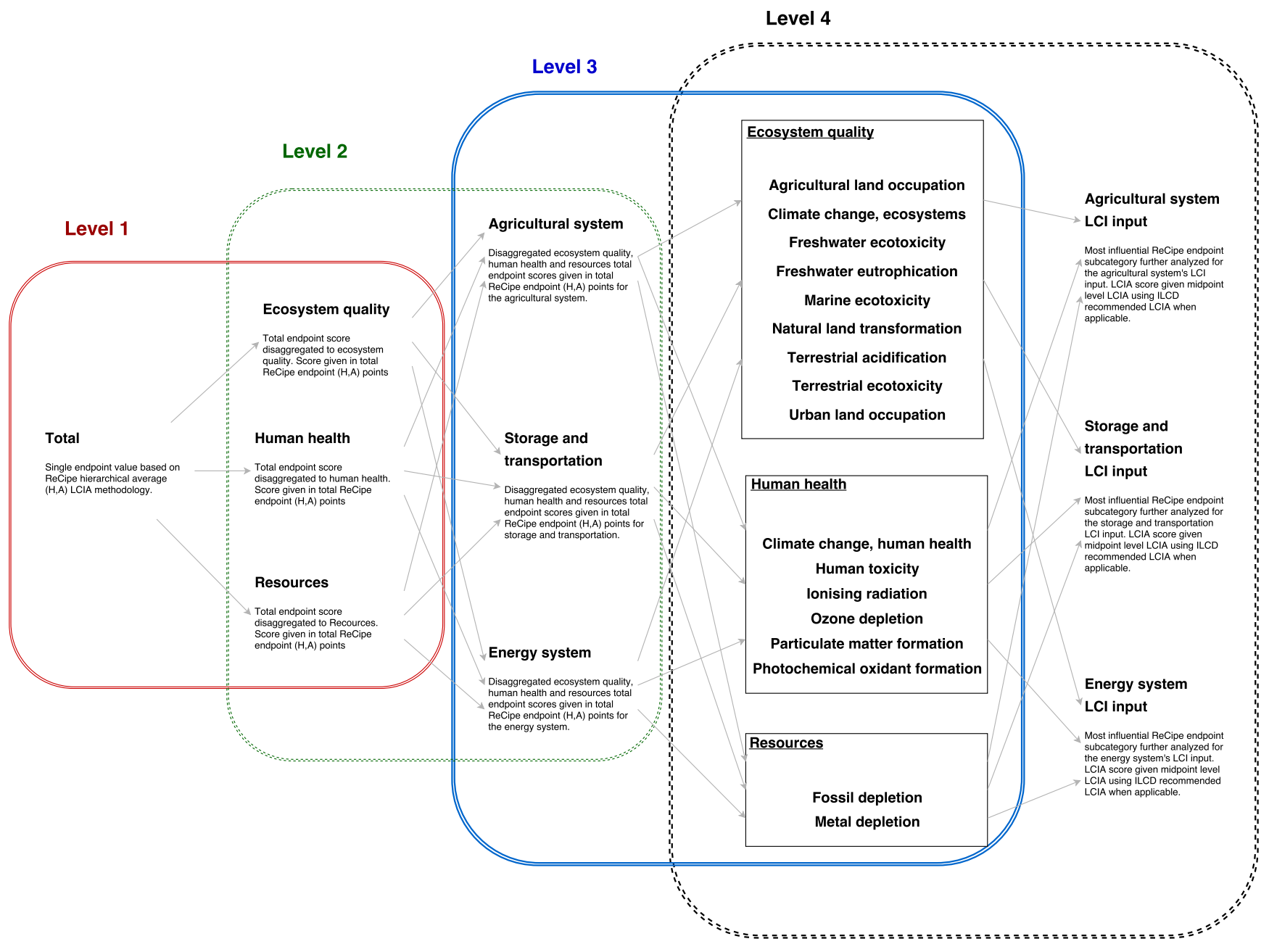

Figure 20. Elements of the four level LCIA method.

tural land occupation, climate change, freshwater ecotoxicity, freshwater eutrophication, marine ecotoxicity, natural land transformation, terrestrial acidification, terrestrial ecotoxicity and urban land occupation; for human health, i.e. climate change, human toxicity, ionizing radiation, ozone depletion, particulate matter formation and photochemical oxidant formation; and for resources, i.e. fossil depletion and metal depletion. Level four then takes the most important impact categories and gives midpoint results for each input and output of the LCI. By doing this the elements of greatest influences to the environmental impact can be identified. For endpoint results the ReCipe method Goedkoop et al. (6 January 2009) is used and the International Reference Life Cycle Data System (ILCD) recommended methods (Hauschild et al. (2010)) are used for the midpoint results.

\section{Model implementation}

Python 2.7 was used to design of the integrated agricultural and bioenergy model. The open source advanced life cycle assessment software Brightway2 Mutel (2015) is imported as a module, which enables easy communication with the Ecoinvent 3 database Weidema et al. (2013) once uploaded. Communication to other software within the model script is done by interacting with the operating system and with file manipulation using the os and shutil python modules, respectively. Pandas is used for data structures and as a data analysis tool to import and manipulate data within the python script, and the numpy module is used for all numerical calculation. A basic flowchart of the main processes it goes through when used is displayed in Figure 21. Figure 21 uses five different objects to describe various functions in the model. Those functions are; internal process, external process, decision, input/output and local database. The meaning behind internal processes is that these objects are created in and operate fully in the python script the model is written in by the author. However, external processes operate outside the model script and an object has been made for communication within the model script. Local databases are also outside of the script model but no processes are operating within them as they simply pass on data to either internal or external processes that operate on them. The decision function basically contains information on what 


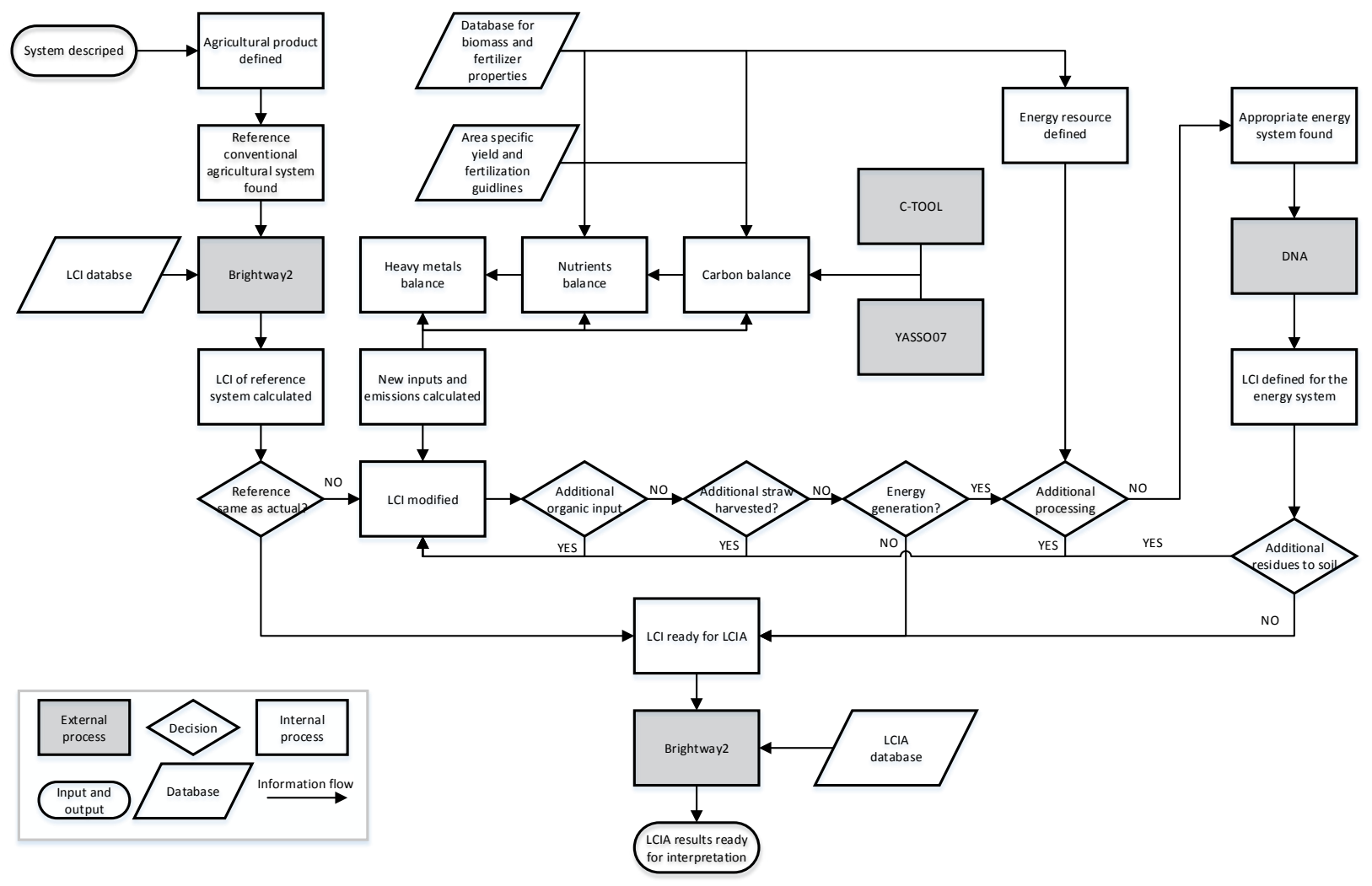

Figure 21. Basic flowchart of the integrated system model.

to do when different cases and/or situations are modeled. Input/output functions communicate information with the user of the model, i.e the input information required to use the model and the output it gives based on those information. The arrows describe the main information flow in the model. It is beneficial to use the case study and its reference to further explain the procedures of the model. Starting with the reference case, the system analyzed is defined, i.e. direct manure application on a field whose main product is wheat grain. The agricultural product of wheat grain is identified and a reference case with a complete LCI is found from the ecoinvent database using Brightway2.

For a wheat grain product the model automatically finds a predefined reference which has similar properties as such a system in Denmark where the case study is located. At this point, a full LCI is ready for LCIA. However, this system is not fully descriptive to the system being analyzed. Therefore, a modification of the LCI generated is required for new unit processes and emissions of the system. This is done by first gathering information about the fertilization requirements and expected yield, then the nutrient-, heavy metal- and carbon balances are made for the new properties of the system. At this point, the agricultural product is produced as the reference but representing specific conditions in Denmark.

Next the model reacts to an additional organic input, e.g. manure, if there are no further organic inputs the LCI is ready for LCIA. If there is an additional organic input the LCI is modified similarly as before, but now balances are made including the organic input with its properties. Likewise, if the straws are removed their properties are removed as-well which affects the balances and the LCI is modified. If the straws are not removed the LCI is ready for LCIA (as the straws are not removed in the reference). The calculation of the LCI is finished here for the reference case.

For the case study the process is the same until the model reacts to additional organic input as there is a liquid manure and an input from the energy sub-system, i.e. digestate. Then the LCI needs to be modified again taking those inputs to consideration. The energy sub-system can be connected to the agricultural sub-system by utilizing its straws but it can also use an external source as done in the case study with the raw pig manure. Either way there is a need to check if additional processes, e.g. storage and/or separation, are required. If the sub-system requires additional processes before resources can be utilized in a power plant the inputs and emissions need to be calculated and LCI is modified.

At this point the appropriate energy sub-system needs to be found which is available and built in DNA prior to running the model. From DNA, all balances are calculated and its data can directly be post-processed into a LCI. Now the LCI in the agricultural sub-system is modified if the residues from the energy sub-system are sent to it and a combined LCI ready for LCIA is fully defined. As described in Section 2.3, there are a few steps the model 
makes when compiling the LCIA results before they are displayed to the user.

\section{Case study results}

LCI tables are given in Appendix A.1 for both the case study and the reference case. Those tables display the inputs and outputs for each sub-system, where the values are given as a changes from conventional wheat production in Denmark. The LCIA results are given in reference to the LCIA levels described in Section 2.3 and in Figure 20. Figure 22 gives the Level 1 endpoint results of the direct field application reference and the biogas production and utilization case.

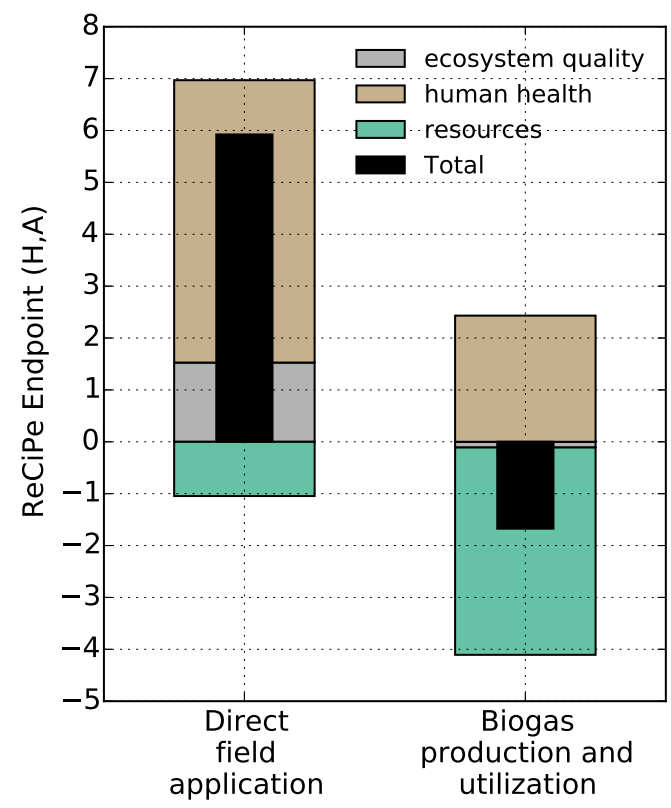

Figure 22. Life Cycle Assessment endpoint results (Level 1).

It can be seen in Figure 22 that the total score of the case study has a lower overall environmental impact then its reference and has a net mitigating environmental effect, whereas the reference has an intensifying effect.

Figure 23 gives the results of the Level 2 analysis, by disaggregating the results from Figure 22 into the main sections of the overall system, i.e. agricultural sub-system, storage and transportation, and energy system, for the three aggregated endpoint categories.

It can be seen in the 23 that the case study outperforms its reference in all three aggregated endpoint LCIA categories. Further, the distribution between the sections indicates large changes in the agricultural sub-system for the ecosystem quality and human health categories, but the largest changes are in the energy sub-system for the resources category. This can be further investigated in a Level 3 analysis. Figures 24 - 26 disaggregate the results from Figure 23 in to subcategories of ecosystem quality, human health and resources, respectively. In Figure 24 it can see that the greatest contributor to the ecosystem quality impact is climate change and there is very little impact in the other subcategories. In the agricultural subsystem both the case study and its reference show a mitigating effect on climate change, but the case study offers considerably greater mitigation. However, in storage and transportation the impact is intensified. There the case study is less intensive than its reference, but for the energy sub-system the case study also has an intensifying effect whereas the reference does not have an impact as it has no processes in the energy sub-system. To further investigate those results it is relevant to take a closer look at the climate change impact in a Level 4 analysis.

Figure 27 in the Appendix, displays the results using the midpoint category IPCC's global warming potential over a 100 time horizon. for each section. But disaggregated to the inputs and outputs of the system in relation to the LCI. In Figure 27a the difference in the impact of the agricultural sub-system can be found to be due to the carbon dioxide emission and the mineral nitrogen fertilizer input. The amount of carbon dioxide emitted from the agricultural sub-system can be found in tables 3 and 4, but the reason can be found in Section 2.2.1. There it is stated that the carbon dioxide emission from the agricultural subsystem is carbon respiration from decaying organic matter in the soil. Digested manure has less carbon then raw manure because a large portion of it is transformed into biogas in the anaerobic digester. The amount of substituted mineral nitrogen fertilization is given in tables 1 and 2 . The reason for greater substitution in the case study can be found in the nitrogen balance of the agricultural subsystem described in Section 2.2.1, there it is stated that less nitrogen in the digested manure is immobilized in the soil compared to nitrogen in raw manure and thus more nitrogen available to the growing plants. It can be observed in Figure 27b that the difference in impact is due to the difference in methane emission. In Section 2.2.3 it is stated that the carbon balance of the storage units is based on Hamelin et al. (2011), where the digested manure has mostly slowly degradable volatile solids and the emissions are based on the amount of volatile solids stored.

The greatest impact factors in the energy sub-system found by observing Figure 27c are the carbon dioxide emission and the substitution of natural gas fueled heat and power generation. The carbon emission is from the carbon that was taken from the manure in the anaerobic digester is the reason for the decrease in carbon emission between the case study and the reference in the agricultural sub-system. What is interesting is that although the net carbon emission from the agricultural and energy subsystems is greater in the case study the substitution of fossil fueled heat and power generation counterweights that and contributes in making the biogas production and utilization case superior to its reference in terms of climate change impact.

Figure 25 displays the human health environmental im- 


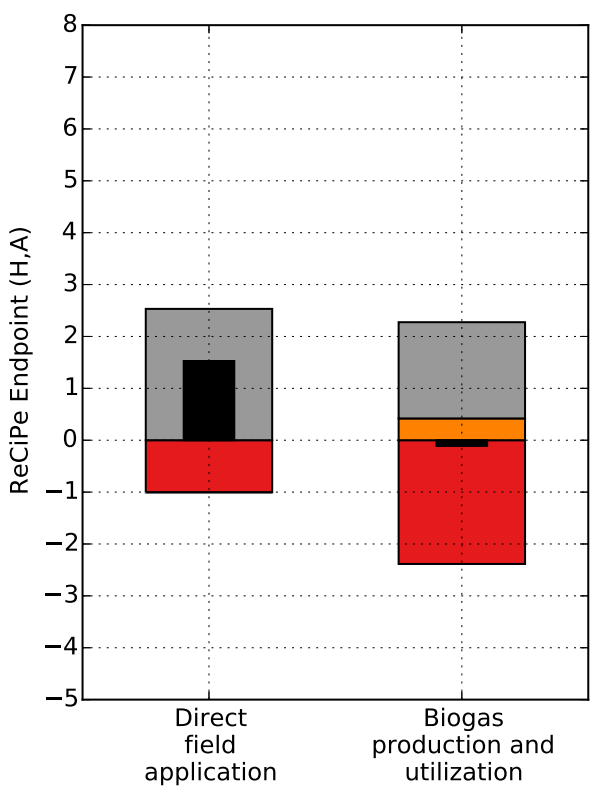

(a) Ecosystem quality.

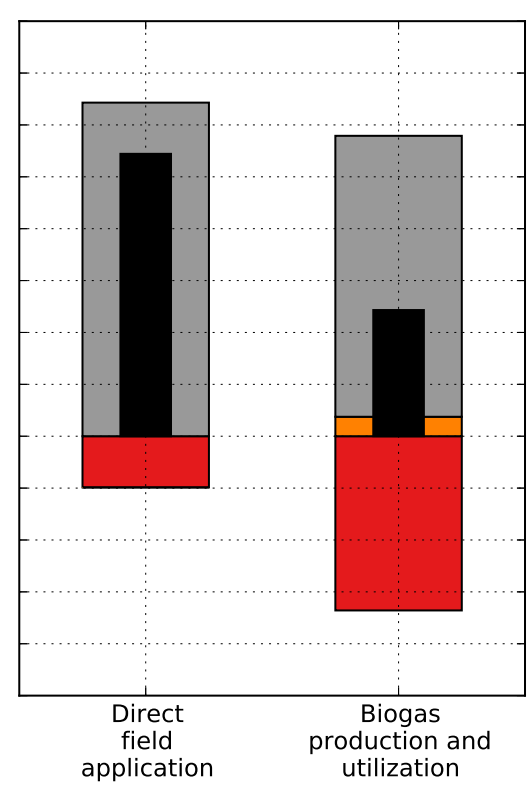

(b) Human health.

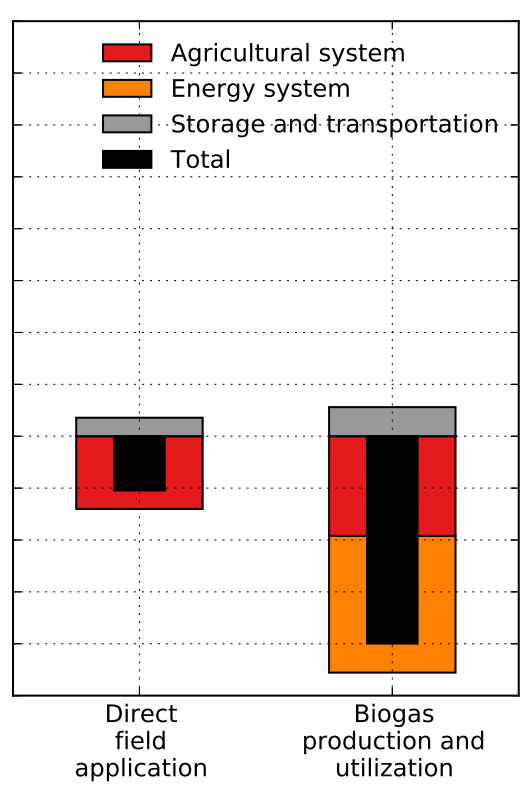

(c) Resources.

Figure 23. Disaggregated Life Cycle Assessment ecosystem quality endpoint results (Level 2).

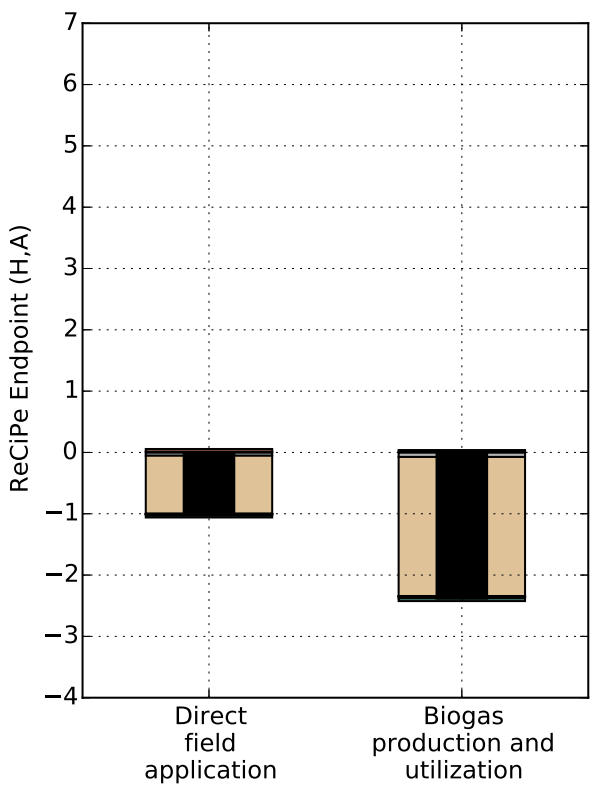

(a) Agricultural sub-system.

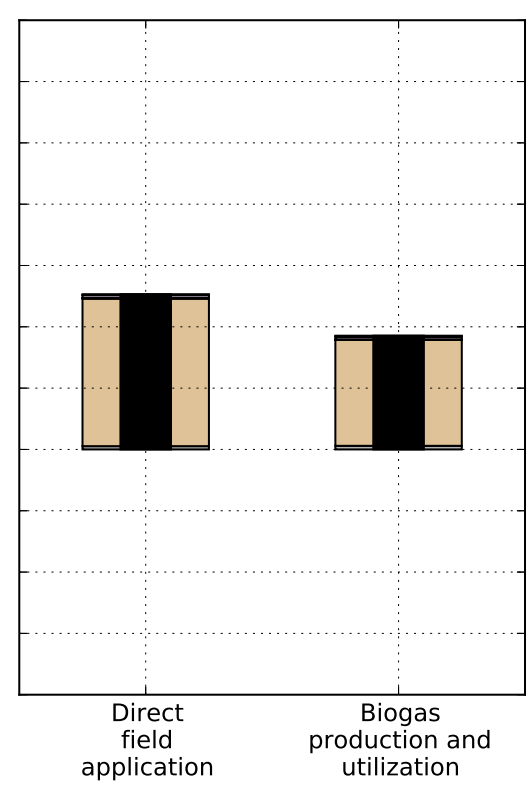

(b) Storage and transportation.

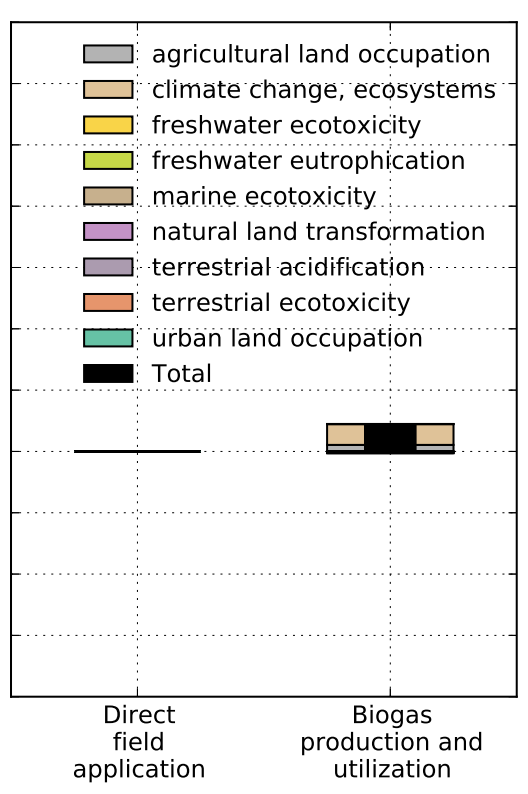

(c) Energy sub-system.

Figure 24. Disaggregated Life Cycle Assessment human health endpoint results.

pact and it can be seen that particulate matter formation and climate change are the largest contributors. Having discussed the climate change impact in depth above, the Level 4 analysis is on the particulate matter formation part of the total environmental impact. From the Figures in 28 it can be seen the main contributor to particulate matter formation is ammonia emission in the agricultural subsystem, and storage and transportation sub-system. The emission of ammonia is calculated in the nitrogen balance in described in Section 2.2.1 and 2.2.3 both are based on
Hamelin et al. (2011) which refers to national guidelines of nitrogen accounting.

In Figure 26, which displays the environmental impact on resources, it can be observed that the greatest category of the two available is fossil depletion. Furthermore, that category is also where the greatest difference is observed between the case study and the reference. From the Figures in 29 the decrease in nitrogen mineral fertilization and the substitution of fossil resources for heat and power generation are most influential. 


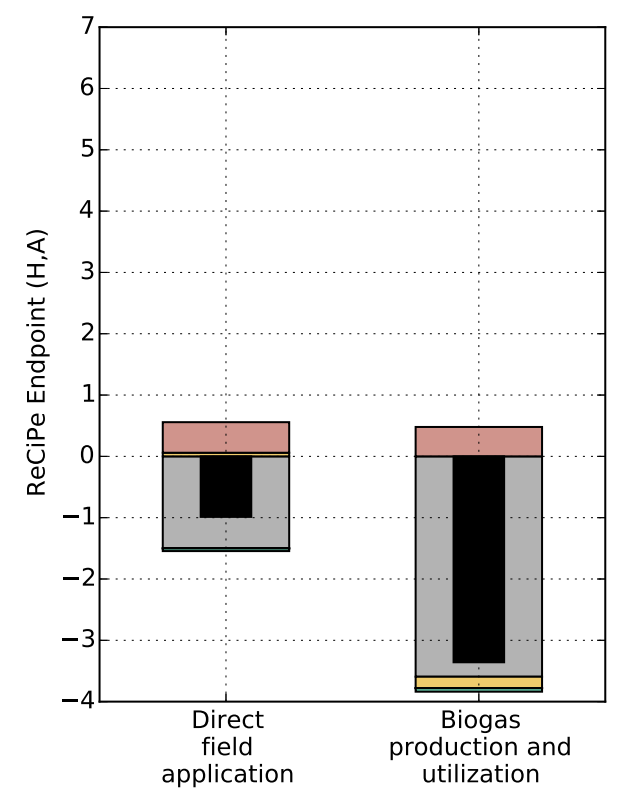

(a) Agricultural sub-system.

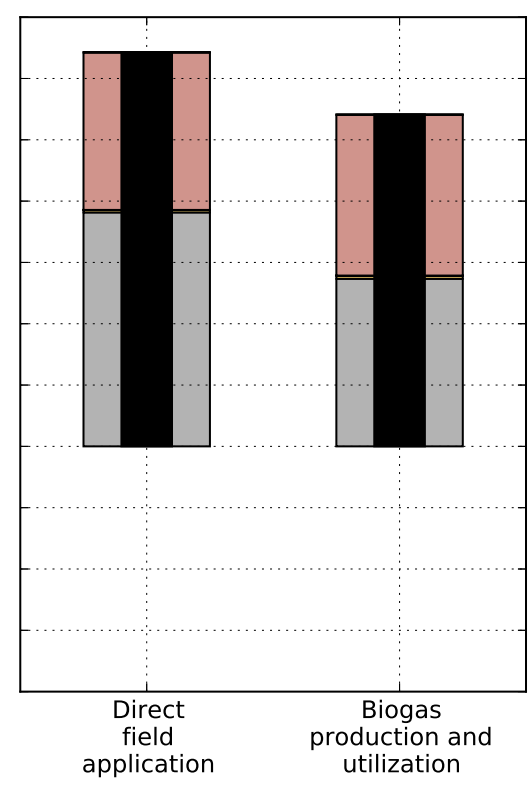

(b) Storage and transportation.

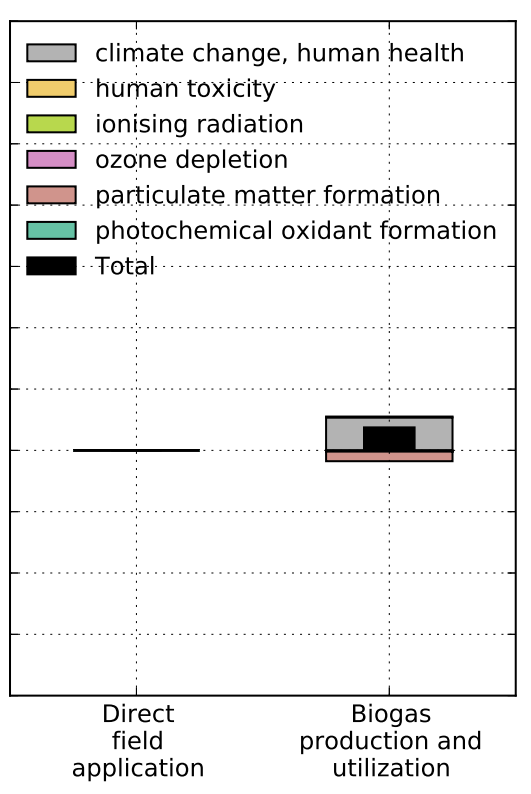

(c) Energy sub-system.

Figure 25. Disaggregated Life Cycle Assessment resources endpoint results.

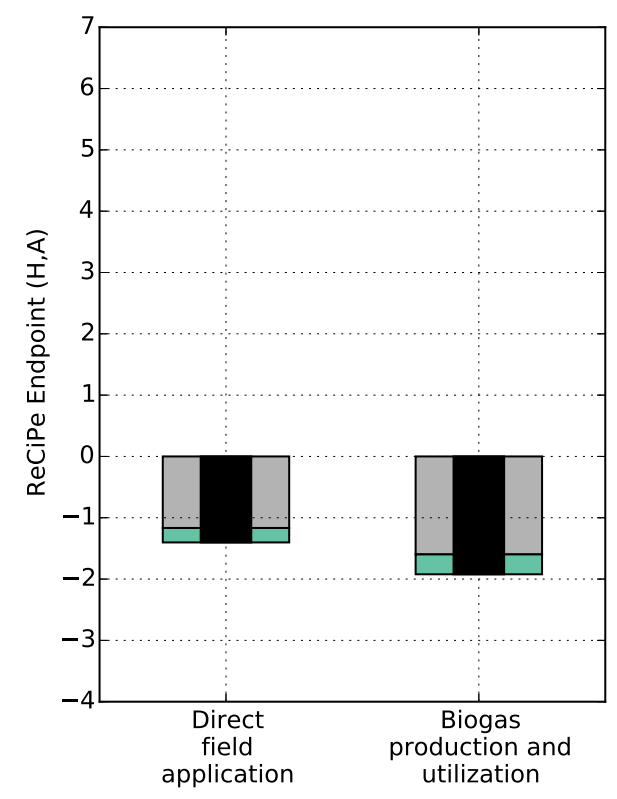

(a) Agricultural sub-system.

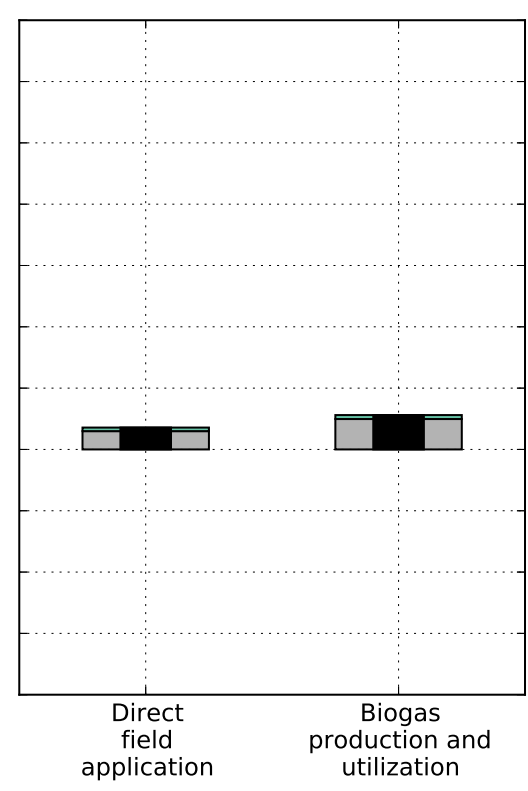

(b) Storage and transportation.

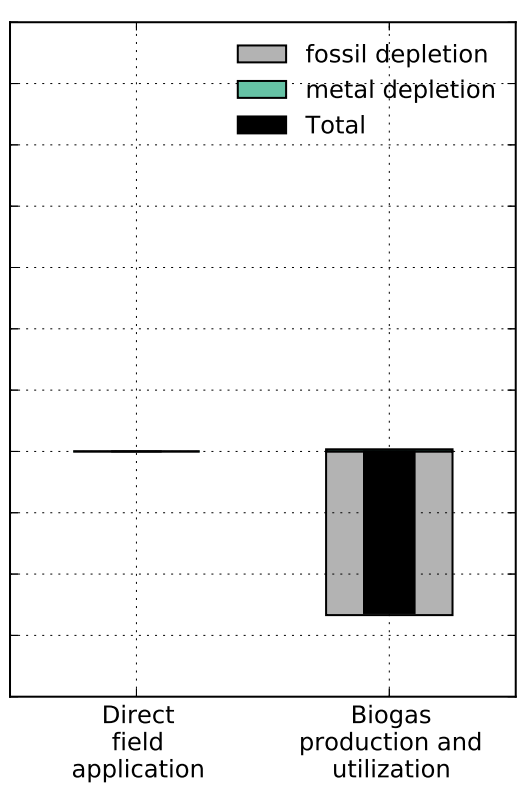

(c) Energy sub-system.

Figure 26. Disaggregated Life Cycle Assessment endpoint results.

\section{Discussion}

When observing the results of the case study, it seems that for a system like these, analyzing the environmental impact categories climate change and fossil depletion, as particulate matter formation was basically the same for the case study and its reference, might by sufficient to reach an informed decisions. There is a general acceptance of the climate change impact method from IPCC and every impact assessment method in general use, uses that approach.
However, this is not the case for resource depletion environmental impact. For that impact category it is generally recognized that improvements are needed (Hauschild et al. (2010)). Although generally not recognized to reflect resource scarcity, which is a requirement by the ILCD for an impact method, exergy and cumulative exergy could be used to reflect the efficiency of resource utilization in a life cycle sense and thus aid in the decision making. It could be added to the overall analysis but outside of the LCA results where an impact method reflecting scarcity would 
be used.

Displaying the results using four levels as introduced in Section 2.3 gives a great deal of insight into the system analyzed. It can also help in finding weaknesses in the modeling, e.g. if one of the greatest contributors is based on uncertain data or the greatest impact is calculated with LCIA method which will need further development. It is also worth noting that the level of detail could be decrease by jumping from level one to level 4 result and showing only the top contributers for main impacts for simplicity.

As mentioned in the introduction, all parts of the processes in the model are freely available. This includes all the external software used. However, the LCI database used in this case study was Ecoinvent3. To be able to use Ecoinvent3 a user will need a license, which is not free of charge. To get around this there are new and constantly expanding freely available LCI databases, e.g. ELCD, USDA, Agribalyse and bioenergiedat.

\section{Conclusion}

The article introduces a model that successfully uses only freely available software to model Life Cycle Assessment of an integrated bioenergy and agriculture sub-system. This was demonstrated with a case study of biogas production from manure and field application of the residual digestate, in reference to direct manure to field application.

The case study unveiled the studied case to be better in terms of overall environmental impact than its reference, where the greatest difference from the reference were observed in the climate change and fossil depletion impact categories.

The model still uses ecoinvent, a commercial LCI database. But with new freely available LCI database, the possibility for a completely free software based on the model introduced is getting greater.

\section{References}

Francesco Cherubini, Anders H. Stromman, and Edgar Hertwich. Effects of boreal forest management practices on the climate impact of $\mathrm{CO} 2$ emissions from bioenergy. Ecological Modelling, 223(1):59-66, December 2011. ISSN 03043800. doi:10.1016/j.ecolmodel.2011.06.021.

Danish Ministry of Climate. Energy and Buildings. OUR FUTURE ENERGY. Technical report, Danish Ministry of Climate. Energy and Buildings, Copenhagen.

P. de Willigen. An analysis of the calculation of leaching and denitrification losses as practised in the NUTMON approach. Rapport-Plant Research International, (18), 2000.

Capucine Dupont, Rodica Chiriac, Guillaume Gauthier, and François Toche. Heat capacity measurements of various biomass types and pyrolysis residues.
Fuel, 115:644-651, January 2014. ISSN 00162361. doi:10.1016/j.fuel.2013.07.086.

Brian Elmegaard and Niels Houbak. Dna: A general energy system simulation tool. Proceedings of SIMS 2005, pages 43-52, 2005.

A. Friedl, E. Padouvas, H. Rotter, and K. Varmuza. Prediction of heating values of biomass fuel from elemental composition. Analytica Chimica Acta, 544(1-2):191-198, July 2005. ISSN 00032670. doi:10.1016/j.aca.2005.01.041.

Rolf Frischknecht. LCI modelling approaches applied on recycling of materials in view of environmental sustainability, risk perception and eco-efficiency. The International Journal of Life Cycle Assessment, 15(7):666-671, June 2010. ISSN 0948-3349. doi:10.1007/s11367-010-0201-6.

M. J. Goedkoop, R Heijungs, M. Huijbregts, A. De Schryver, J. Struijs, and R. Van Zelm. Recipe 2008, a life cycle impact assessment method which comprises harmonised category indicators at the midpoint and the endpoint level; first edition report i: Characterisation. Technical report, 6 January 2009. Homepage: http://www.lcia-recipe.net/.

The Danish Government. The Danish Climate Policy Plan Towards a low carbon society. Technical report, Danish Government, Copenhagen, 2013a. Retrieved from: http://www.ens.dk/sites/ens.dk/files/policy/danish-climateenergy-policy/danishclimatepolicyplan_uk.pdf.

The Danish Government. Catalogue of Danish Climate Change Mitigation Measures. Technical report, Danish Government, Copenhagen, 2013b. Retrienved from: http://www.ens.dk/sites/ens.dk/files/policy/danish-climateenergy-policy/dk_climate_change_mitigation_uk.pdf.

Lorie Hamelin, Marianne Waesnes, Henrik Wenzel, and Bjorn M Petersen. Environmental consequences of future biogas technologies based on separated slurry. Environmental science \& technology, 45(13):5869-77, July 2011. ISSN 1520-5851. doi:10.1021/es200273j.

Michael Hauschild, GOEDKOOP Mark, GUINEE Jerome, HEIJUNGS Reinout, HUIJBREGTS Mark, JOLLIET Olivier, MARGNI Manuele, and DE SCHRYVER An. Recommendations for Life Cycle Impact Assessment in the European context - based on existing environmental impact assessment models and factors (International Reference Life Cycle Data System - ILCD handbook), October 2010. ISSN 1018-5593.

Fortunat Joos, Michele Bruno, Roger Fink, Ulrich Siegenthaler, Thomas F. Stocker, Corinne Le Quere, and Jorge L. Sarmiento. An efficient and accurate representation of complex oceanic and biospheric models of anthropogenic carbon uptake. Tellus B, 48(3):397-417, July 1996. ISSN 02806509. doi:10.1034/j.1600-0889.1996.t01-2-00006.x.

Fortunat Joos, I. Colin Prentice, Stephen Sitch, Robert Meyer, Georg Hooss, Gian-Kasper Plattner, Stefan Gerber, and Klaus Hasselmann. Global warming feedbacks on terrestrial carbon uptake under the Intergovernmental Panel on Climate Change (IPCC) Emission Scenarios. Global Biogeochemical Cycles, 15(4):891-907, December 2001. ISSN 08866236. doi:10.1029/2000GB001375. 
Jari Liski, Taru Palosuo, Mikko Peltoniemi, and Risto Sievänen. Carbon and decomposition model Yasso for forest soils. Ecological Modelling, 189(1-2):168-182, November 2005. ISSN 03043800. doi:10.1016/j.ecolmodel.2005.03.005.

Chris Mutel. Brightway2, $2015 . \quad$ Homepage: www.brightwaylca.org.

NaturErhvervstyrelsen. Vejledning om gØdsknings- og harmoniregler. Technical report, Ministeriet for Fødevarer, Landbrug og Fiskeri, 2013.

Thomas Nemecek and Julian Schnetzer. Methods of assessment of direct field emissions for LCIs of agricultural production systems. Data v3. 0, 2012.

D.W. Pennington, J. Potting, G. Finnveden, E. Lindeijer, O. Jolliet, T. Rydberg, and G. Rebitzer. Life cycle assessment part 2: Current impact assessment practice. Environment International, 30(5):721 - 739, $2004 . \quad$ ISSN 0160-4120. doi:http://dx.doi.org/10.1016/j.envint.2003.12.009.

Bjorn M. Petersen, Jorgen E. Olesen, and Tove Heidmann. A flexible tool for simulation of soil carbon turnover. Ecological Modelling, 151(1):1-14, May 2002. ISSN 03043800. doi:10.1016/S0304-3800(02)00034-0.

Bjorn M. Petersen, Lars S. Jensen, Sø ren Hansen, Anders Pedersen, Trond M. Henriksen, Peter S $\varnothing$ rensen, Isabelle Trinsoutrot-Gattin, and Jø rgen Berntsen. CN-SIM: a model for the turnover of soil organic matter. II. Short-term carbon and nitrogen development. Soil Biology and Biochemistry, 37(2):375-393, February 2005. ISSN 00380717. doi:10.1016/j.soilbio.2004.08.007.

Bjorn Molt Petersen, Marie Trydeman Knudsen, John Erik Hermansen, and Niels Halberg. An approach to include soil carbon changes in life cycle assessments. Journal of Cleaner Production, 52:217-224, August 2013. ISSN 09596526. doi:10.1016/j.jclepro.2013.03.007.

G. Rebitzer, T. Ekvall, R. Frischknecht, D. Hunkeler, G. Norris, T. Rydberg, W.-P. Schmidt, S. Suh, B.P. Weidema, and D.W. Pennington. Life cycle assessment: Part 1: Framework, goal and scope definition, inventory analysis, and applications. Environment International, 30(5):701 - 720, 2004. ISSN 0160-4120. doi:http://dx.doi.org/10.1016/j.envint.2003.11.005.

R. N. Roy, R.V. Misra, J.P. Lesschen, and E.M. Smaling. Assessment of soil nutrient balance: Approaches and methodologies. Technical report, Food and Agriculture Organization of the United Nations, 2003. Retrieved from: ftp://ftp.fao.org/docrep/fao/006/y5066e/y5066e00.pdf.

Jon Schnute. A Versatile Growth Model with Statistically Stable Parameters. Canadian Journal of Fisheries and Aquatic Sciences, 38(9):1128-1140, September 1981. ISSN 0706-652X. doi:10.1139/f81-153.

Sangwon Suh and Gjalt Huppes. Methods for life cycle inventory of a product. Journal of Cleaner Production, 13(7):687 - 697, 2005. ISSN 0959-6526. doi:http://dx.doi.org/10.1016/j.jclepro.2003.04.001.
Stanislav V. Vassilev, David Baxter, Lars K. Andersen, and Christina G. Vassileva. An overview of the chemical composition of biomass. Fuel, 89(5):913-933, May 2010. ISSN 00162361. doi:10.1016/j.fuel.2009.10.022.

B.P. Weidema, Ch. Bauer, R. Hischier, Ch. Mutel, T. Nemecek, J. Reinhard, C.O. Vadenbo, and G. Wernet. The ecoinvent database: Overview and methodology, Data quality guideline for the database version 3, 2013. Homepage: www.ecoinvent.org. 


\section{A Appendix}

\section{A.1 LCI data}

Table 1. Life Cycle Inventory for processes, direct field application.

\begin{tabular}{llrr}
\hline & Unit & Agricultural & Storage and trans. \\
\hline market for potassium chloride, as K2O & kilogram & -75.735 & 0.000 \\
liquid manure spreading, by vacuum tanker & cubic meter & 21.283 & 0.000 \\
market for phosphate fertiliser, as P2O5 & kilogram & -43.510 & 0.000 \\
market for nitrogen fertiliser, as N & kilogram & -116.115 & 0.000 \\
market for fertilising, by broadcaster & hectare & -3.263 & 0.000 \\
transport, tractor and trailer, agricultural & ton kilometer & 0.000 & 445.265 \\
market for electricity, low voltage & kilowatt hour & 0.000 & 15.916 \\
market for liquid manure storage and processing.... & cubic meter & 0.000 & 0.001 \\
\hline
\end{tabular}

Table 2. Life Cycle Inventory for emissions, direct field application.

\begin{tabular}{llrr}
\hline & Unit & Agricultural & Storage and trans. \\
\hline Phosphate & kilogram & 0.134 & 0.000 \\
Carbon dioxide, fossil & kilogram & -3151.968 & 0.000 \\
Zinc & kilogram & 1.216 & 0.000 \\
Copper & kilogram & 0.183 & 0.000 \\
Ammonia & kilogram & 12.568 & 0.000 \\
Dinitrogen monoxide & kilogram & 0.322 & 0.000 \\
Mercury & kilogram & 0.001 & 0.000 \\
Nitrogen oxides & kilogram & -0.274 & 0.000 \\
Nitrate & kilogram & -1.264 & 0.000 \\
Chromium & kilogram & -0.007 & 0.000 \\
Carbon dioxide, from soil or biomass stock & kilogram & 2376.740 & 0.000 \\
Lead & kilogram & 0.001 & 0.000 \\
Cadmium & kilogram & -0.001 & 0.000 \\
Nickel & kilogram & 0.010 & 0.000 \\
Methane, from soil or biomass stock & kilogram & 0.000 & 69.100 \\
Ammonia & kilogram & 0.000 & 31.519 \\
Dinitrogen monoxide & kilogram & 0.000 & 3.676 \\
Nitrogen oxides & kilogram & 0.000 & 1.932 \\
Nitrogen & kilogram & 0.000 & 5.410 \\
Carbon dioxide, from soil or biomass stock & kilogram & 0.000 & 57.454 \\
\hline
\end{tabular}


Table 3. Life Cycle Inventory for processes, biogas production and utilization.

\begin{tabular}{|c|c|c|c|c|}
\hline & Unit & Agricultural & Storage and trans. & Energy \\
\hline market for fertilising, by broadcaster & hectare & -3.475 & 0.000 & 0.000 \\
\hline liquid manure spreading, by vacuum tanker & cubic meter & 21.685 & 0.000 & 0.000 \\
\hline market for potassium chloride, as $\mathrm{K} 2 \mathrm{O}$ & kilogram & -75.735 & 0.000 & 0.000 \\
\hline market for phosphate fertiliser, as $\mathrm{P} 2 \mathrm{O} 5$ & kilogram & -43.510 & 0.000 & 0.000 \\
\hline market for nitrogen fertiliser, as $\mathrm{N}$ & kilogram & -129.017 & 0.000 & 0.000 \\
\hline market for polyacrylamide & kilogram & 0.000 & 0.000 & 20.002 \\
\hline transport, tractor and trailer, agricultural & ton kilometer & 0.000 & 0.000 & 427.653 \\
\hline market for electricity, low voltage & kilowatt hour & 0.000 & 0.000 & 64.168 \\
\hline market for liquid manure storage and processing... & cubic meter & 0.000 & 0.000 & 0.001 \\
\hline anaerobic digestion plant construction, agricul... & unit & 0.000 & 0.000 & 0.000 \\
\hline heat and power co-generation, natural gas, $1 \mathrm{MW} \ldots$ & megajoule & 0.000 & -7548.223 & 0.000 \\
\hline heat and power co-generation, natural gas, $1 \mathrm{MW} \ldots$ & kilowatt hour & 0.000 & -1822.929 & 0.000 \\
\hline heat and power co-generation unit construction,... & unit & 0.000 & 0.000 & 0.000 \\
\hline heat and power co-generation unit construction,... & unit & 0.000 & 0.000 & 0.000 \\
\hline heat and power co-generation unit construction,... & unit & 0.000 & 0.000 & 0.000 \\
\hline market for lubricating oil & kilogram & 0.000 & 0.533 & 0.000 \\
\hline market for waste mineral oil & kilogram & 0.000 & -0.533 & 0.000 \\
\hline
\end{tabular}

Table 4. Life Cycle Inventory for emissions, dbiogas production and utilization.

\begin{tabular}{|c|c|c|c|c|}
\hline & Unit & Agricultural & Storage and trans. & Energy \\
\hline Lead & kilogram & -0.000 & 0.000 & 0.000 \\
\hline Cadmium & kilogram & -0.001 & 0.000 & 0.000 \\
\hline Chromium & kilogram & -0.011 & 0.000 & 0.000 \\
\hline Carbon dioxide, fossil & kilogram & -3151.968 & 0.000 & 0.000 \\
\hline Phosphate & kilogram & 0.134 & 0.000 & 0.000 \\
\hline Nickel & kilogram & 0.004 & 0.000 & 0.000 \\
\hline Carbon dioxide, from soil or biomass stock & kilogram & 1533.367 & 0.000 & 0.000 \\
\hline Nitrogen oxides & kilogram & -0.281 & 0.000 & 0.000 \\
\hline Ammonia & kilogram & 10.933 & 0.000 & 0.000 \\
\hline Copper & kilogram & 0.106 & 0.000 & 0.000 \\
\hline Nitrate & kilogram & 19.052 & 0.000 & 0.000 \\
\hline Dinitrogen monoxide & kilogram & 0.730 & 0.000 & 0.000 \\
\hline Zinc & kilogram & 0.703 & 0.000 & 0.000 \\
\hline Mercury & kilogram & 0.001 & 0.000 & 0.000 \\
\hline Methane, from soil or biomass stock & kilogram & 0.000 & 0.000 & 36.086 \\
\hline Carbon dioxide, from soil or biomass stock & kilogram & 0.000 & 0.000 & 34.204 \\
\hline Nitrogen oxides & kilogram & 0.000 & 0.000 & 1.706 \\
\hline Nitrogen & kilogram & 0.000 & 0.000 & 4.778 \\
\hline Ammonia & kilogram & 0.000 & 0.000 & 32.096 \\
\hline Dinitrogen monoxide & kilogram & 0.000 & 0.000 & 3.357 \\
\hline Methane, from soil or biomass stock & kilogram & 0.000 & 5.719 & 0.000 \\
\hline NMVOC, non-methane volatile organic compounds, ... & kilogram & 0.000 & 0.036 & 0.000 \\
\hline Platinum & kilogram & 0.000 & 0.000 & 0.000 \\
\hline Sulfur dioxide & kilogram & 0.000 & 1.067 & 0.000 \\
\hline Carbon monoxide, from soil or biomass stock & kilogram & 0.000 & 0.854 & 0.000 \\
\hline Dinitrogen monoxide & kilogram & 0.000 & 0.044 & 0.000 \\
\hline Nitrogen oxides & kilogram & 0.000 & 0.267 & 0.000 \\
\hline Carbon dioxide, from soil or biomass stock & kilogram & 0.000 & 1492.460 & 0.000 \\
\hline
\end{tabular}




\section{A.2 LCIA level 4 results}

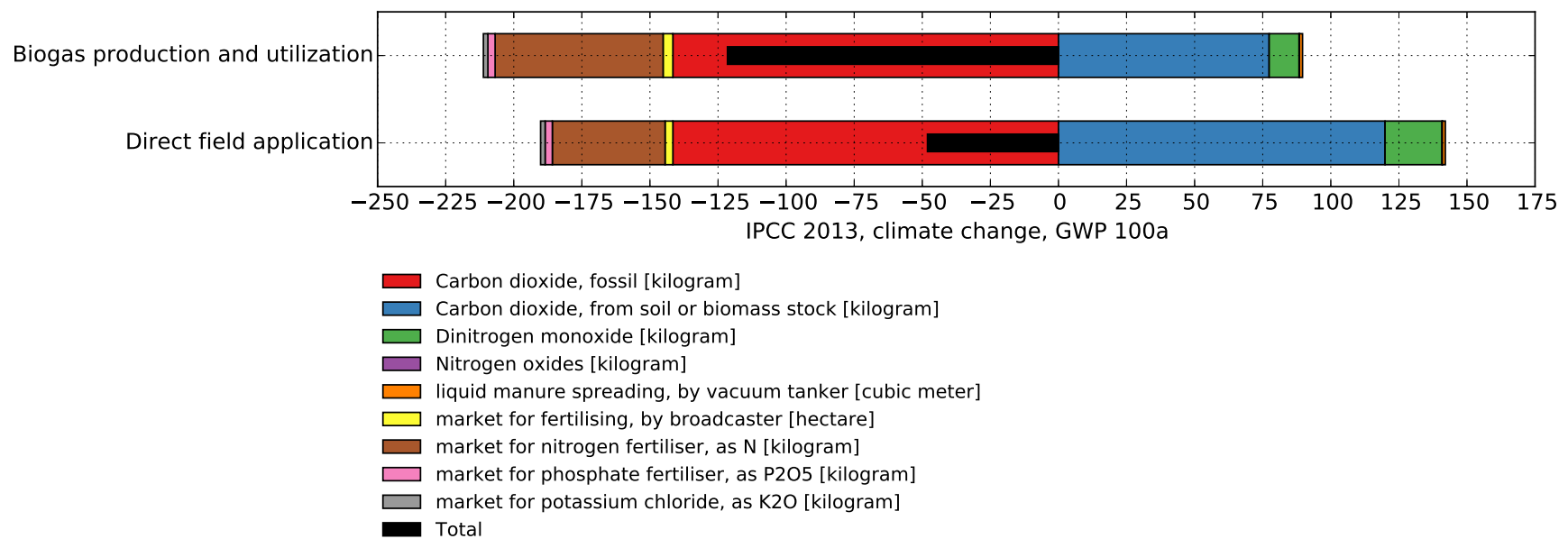

(a) Agricultural system.

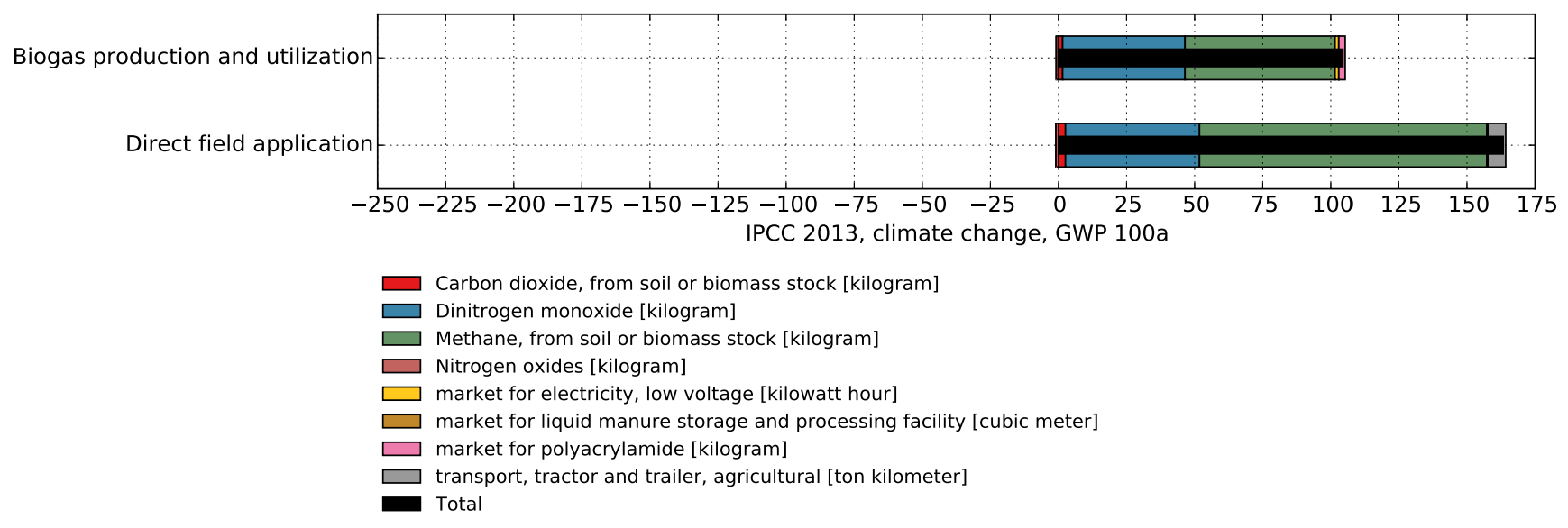

(b) Storage and transportation.

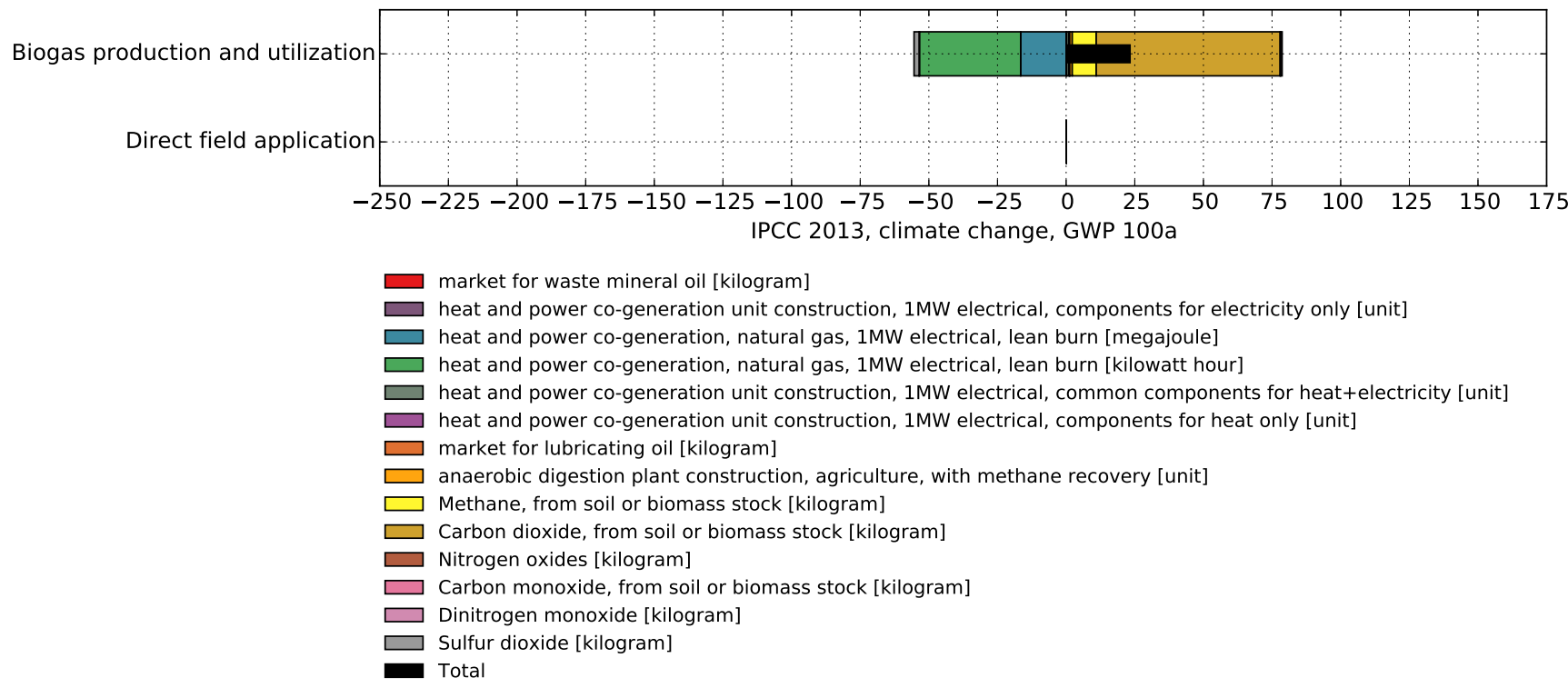

(c) Energy system.

Figure 27. Level 4 climate change, disaggregated LCIA midpoint results in kg Carbon dioxide-equivalence per hectare. 


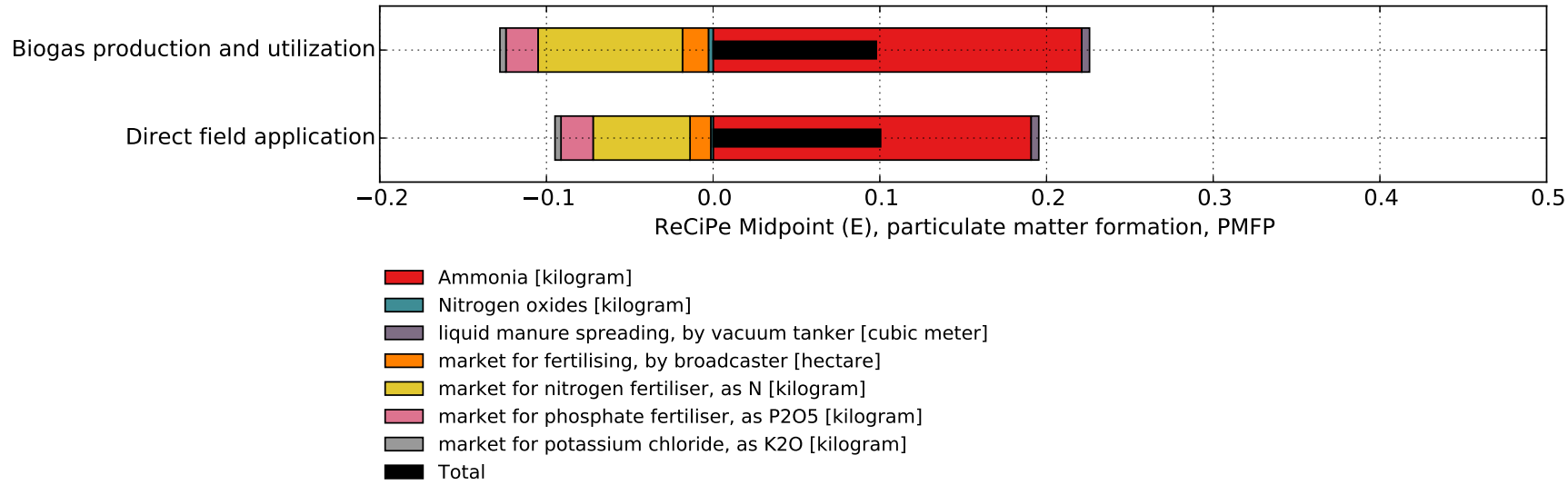

(a) Agricultural system.

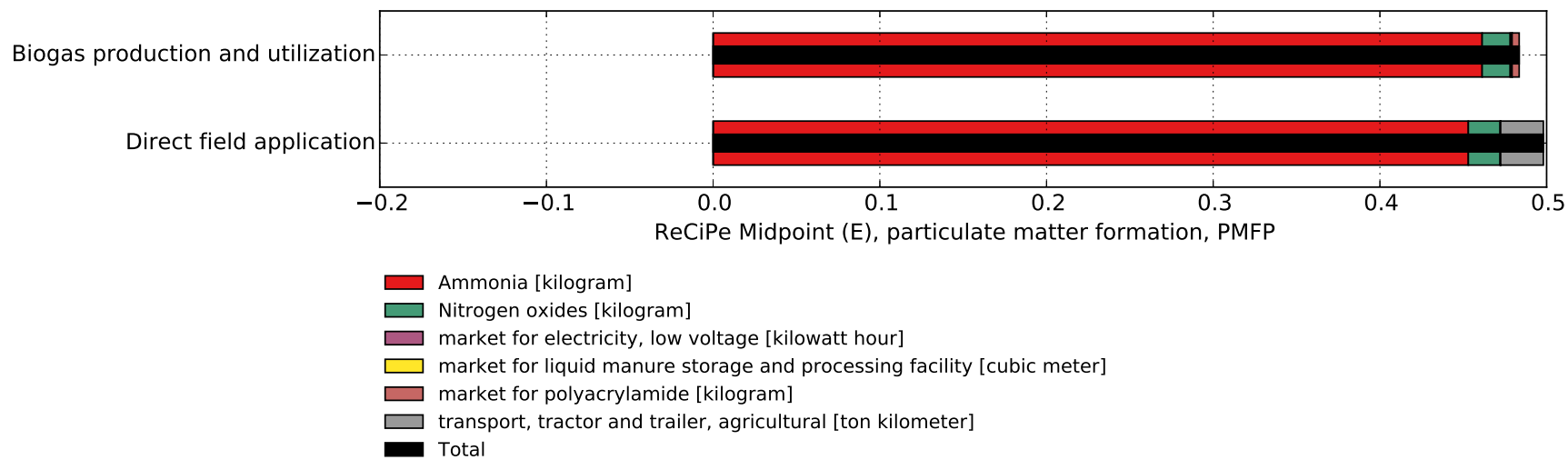

(b) Storage and transportation.

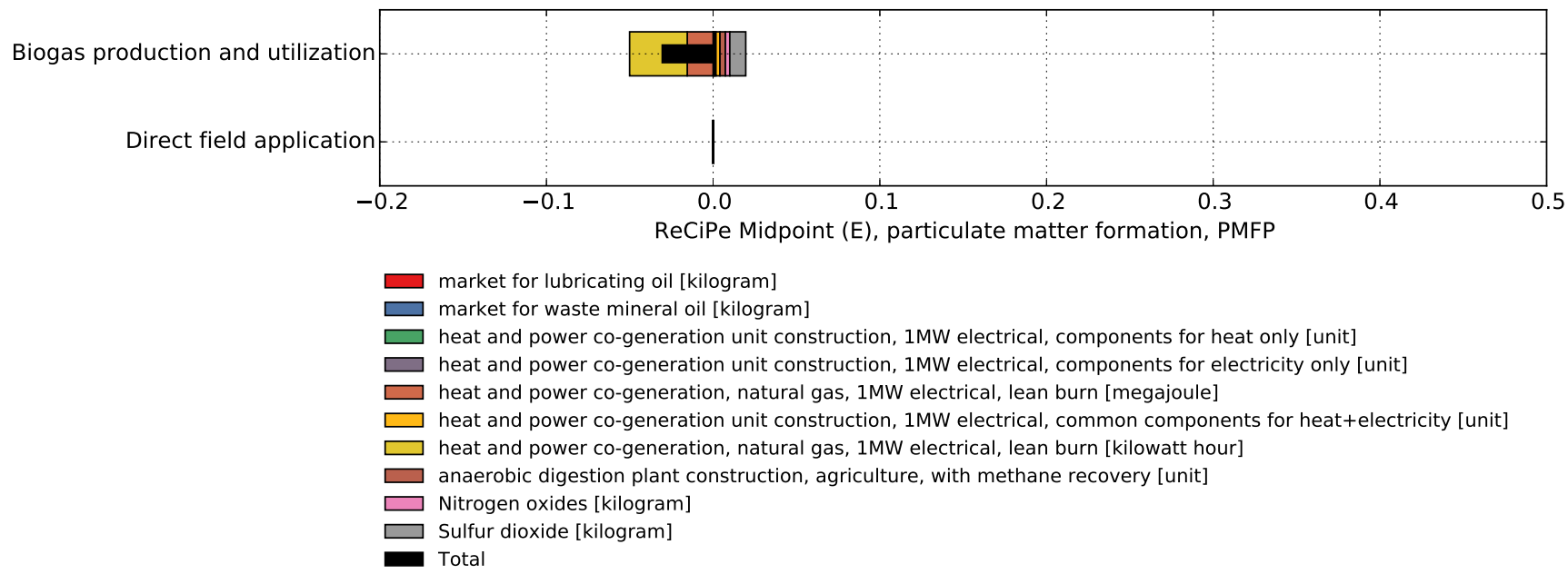

(c) Energy system.

Figure 28. Level 4 particulate matter formation, disaggregated LCIA midpoint results in kg PM10-equivalence per hectare. 


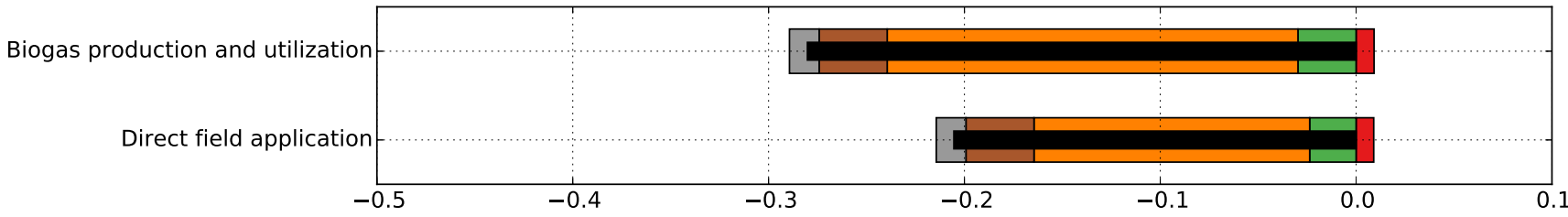

CML 2001, resources, depletion of abiotic resources

$\square$ liquid manure spreading, by vacuum tanker [cubic meter]

$\square$ market for fertilising, by broadcaster [hectare]

$\square$ market for nitrogen fertiliser, as N [kilogram]

$\square$ market for phosphate fertiliser, as P2O5 [kilogram]

$\square$ market for potassium chloride, as K2O [kilogram]

Total

(a) Agricultural system.

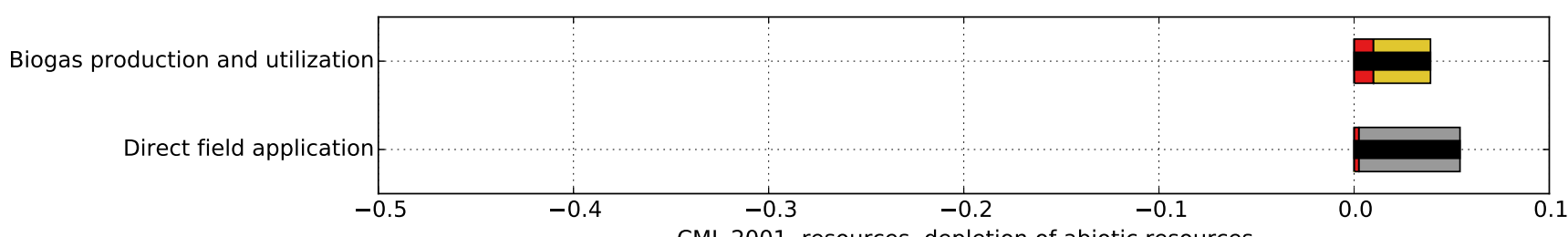

CML 2001, resources, depletion of abiotic resources

$\square$ market for electricity, low voltage [kilowatt hour]

$\square$ market for liquid manure storage and processing facility [cubic meter]

$\square$ market for polyacrylamide [kilogram]

$\square$ transport, tractor and trailer, agricultural [ton kilometer]

Total

(b) Storage and transportation.

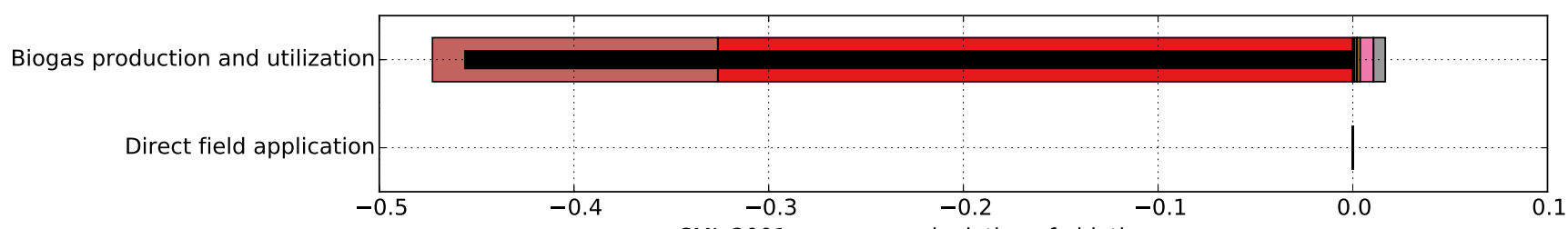

CML 2001, resources, depletion of abiotic resources

heat and power co-generation, natural gas, $1 \mathrm{MW}$ electrical, lean burn [kilowatt hour]

market for lubricating oil [kilogram]

$\square$ heat and power co-generation unit construction, $1 \mathrm{MW}$ electrical, components for electricity only [unit]

$\square$ heat and power co-generation, natural gas, $1 \mathrm{MW}$ electrical, lean burn [megajoule]

$\square$ market for waste mineral oil [kilogram]

$\square$ heat and power co-generation unit construction, $1 \mathrm{MW}$ electrical, components for heat only [unit]

$\square$ heat and power co-generation unit construction, $1 \mathrm{MW}$ electrical, common components for heat+electricity [unit]

$\square$ anaerobic digestion plant construction, agriculture, with methane recovery [unit]

Total

(c) Energy system.

Figure 29. Level 4 depletion of abiotic resources, disaggregated LCIA midpoint results in kg Antimony-equivalence per hectare. 